ENERGY DIVISION

\title{
FLEET VEHICLES IN THE UNTTED STATES: COMPOSITION, OPERATING CHARACTERISTICS, AND FUELING PRACTICES
}

\author{
Shaw-Pin Miaou \\ Patricia S. Hu \\ Jennifer R. Young*
}

*The University of Tennessee, Knoxville, Tennessee

Date Published - May 1992

\author{
Prepared for \\ Office of Transportation Technologies \\ and \\ Office of Policy, Planning, and Analysis \\ U.S. Department of Energy \\ Washington, D.C. 20585
}

\author{
Prepared by \\ OAK RIDGE NATIONAL LABORATORY \\ Oak Ridge, Tennessee 37831 \\ managed by \\ MARTIN MARIETTA ENERGY SYSTEMS, INC. \\ for the \\ U.S. DEPARTMENT OF ENERGY \\ under Contract No. DE-AC05-84OR21400
}

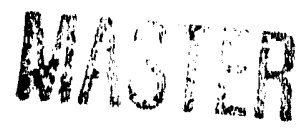




\section{T'ABLE OF CONTENTS}

ACKNOWLEDGEMENTS $\ldots \ldots \ldots \ldots \ldots \ldots \ldots \ldots \ldots \ldots \ldots \ldots \ldots \ldots \ldots$

ABSTRACT $\ldots \ldots \ldots \ldots \ldots \ldots \ldots \ldots \ldots \ldots \ldots \ldots \ldots \ldots \ldots \ldots \ldots \ldots \ldots \ldots$

1.0 INTRODUCTION $\ldots \ldots \ldots \ldots \ldots \ldots \ldots \ldots \ldots \ldots \ldots \ldots \ldots \ldots \ldots \ldots$

2.0 FIEET DEFINITIONS $\ldots \ldots \ldots \ldots \ldots \ldots \ldots \ldots \ldots \ldots \ldots \ldots \ldots \ldots$

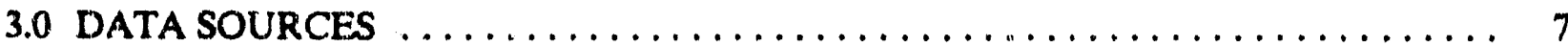

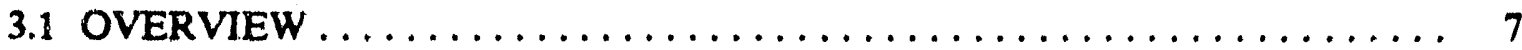

3.2 DATA COLLECTION METHOD $\ldots \ldots \ldots \ldots \ldots \ldots \ldots \ldots \ldots \ldots \ldots$

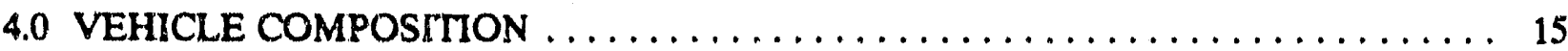

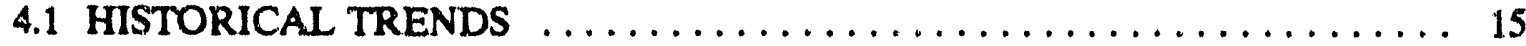

4.2 FLEET COMPOSITION $\ldots \ldots \ldots \ldots \ldots \ldots \ldots \ldots \ldots \ldots \ldots \ldots \ldots$

4.2 .1 Vehicle Size and Type ......................... 19

4.2 .2 Vehicle Makes .......................... 22

4.2.3 Type of Business Vehicle Program . . . . . . . . . . . 22

4.2 .4 Vehicle Weight .......................... 25

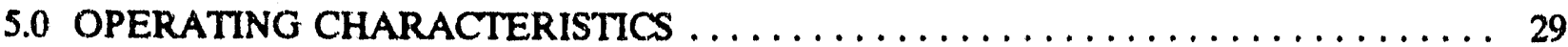

5.1 VEHICLE AGE, REPLACEMENT PLANS, AND PURCHASE DECISIONS ................................. 29

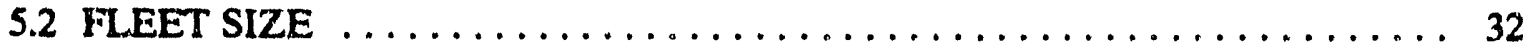

5.5 ANNUAL VEHICLE MILES AND DAIL Y DRIVING RANGE . . . . . . 34

5.4 NUMBER AND TYPES OF GARAGE LOCATIONS . . . . . . . . . . . . 39

6.0 FUELING $\mathrm{RRACTICE} \ldots \ldots \ldots \ldots \ldots \ldots \ldots \ldots \ldots \ldots \ldots \ldots \ldots \ldots \ldots$

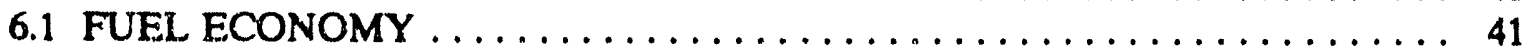

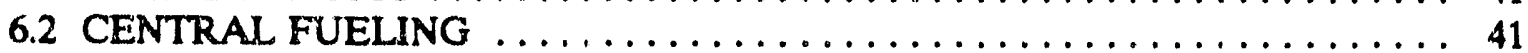

6.3 ALTERNATTVE FUEL VEHICLES $\ldots \ldots \ldots \ldots \ldots \ldots \ldots \ldots \ldots \ldots \ldots \ldots \ldots$

7.0 FUTURE DATA NEEDS $\ldots \ldots \ldots \ldots \ldots \ldots \ldots \ldots \ldots \ldots \ldots \ldots \ldots$

8.0 REFERENCES $\ldots \ldots \ldots \ldots \ldots \ldots \ldots \ldots \ldots \ldots \ldots \ldots \ldots \ldots \ldots \ldots \ldots \ldots$

APPENDIX A $\ldots \ldots \ldots \ldots \ldots \ldots \ldots \ldots \ldots \ldots \ldots \ldots \ldots \ldots \ldots \ldots \ldots \ldots \ldots \ldots$

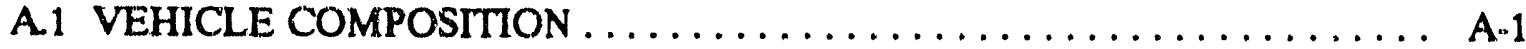

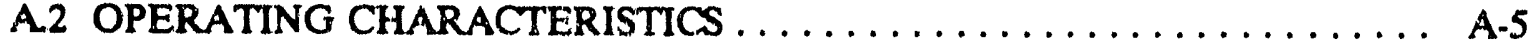

A.3 FUELING PRACTICES $\ldots \ldots \ldots \ldots \ldots \ldots \ldots \ldots \ldots \ldots \ldots \ldots \ldots$ A-6

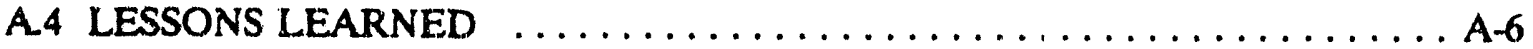




\section{LIST OF TABLES}

Table 1. Sources of Fleet Data Considered in This Study: Target Population,

Sampling Method, and Sample Sizes . . . . . . . . . . . . . . . 11

Table 2. U.S. Passenger Car Registrations and New Car Retail Sales:

Total vs. Fleet of 10 or More. . . . . . . . . . . . . . . 16

Table 3. U.S. Passenger Cars in Fleets by Type of Business

(including both owned and leased) $\ldots \ldots \ldots \ldots \ldots \ldots \ldots \ldots \ldots \ldots$

Table 4. Publicly-Owned Vehicles - Highway Statistics [FHWA, annual] $\ldots \ldots \ldots \ldots$

Table 5. Composition of Typical Vehicle Fleets by Business Type: Runzheimer . . . . . . . 20

Table 6. Composition of light trucks and van fleets in year 1991: Runzheimer ........ 20

Table 7. Fleet ws. Non-Fleet: New Car Registrations (in millions) by Model Year

and Vehicle Size [Bobit Publishing Company, annual] . . . . . . . . . . 21

Table 8. Vehicle Composition of Five Business Fleet Types - Easton Consultants, Inc.

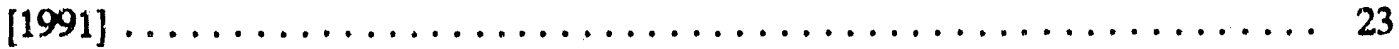

Table 9. Trends in the Types of Business Vehicle Programs: Runzheimer . . . . . . . . . 24

Table 10. Composition of Fleet Vehicles by Whether They are Company-owned, leased, or

Employee-provided: Bobit Publishing Company $\ldots \ldots \ldots \ldots$

Table 11. Federal Civilian Agencies (Including Postal Service) in-use Domestic Vehicles and their Operating Characteristics in Fiscal Year $1988 \ldots \ldots \ldots \ldots \ldots \ldots$

Table 12. The Average Length of Time Vehicles are Kept Before Sold to Others:

ORNL/DOE study. .......................... 30

Table 13. Selling Methods of Fleet Vehicles: NAFA's Used-Vehicle Marketing Survey

[Bobit Publishing Company, annual] ................. 31

Table 14. Estimated Fleet Size for Five Business Categories - Easton Consultants, Inc.

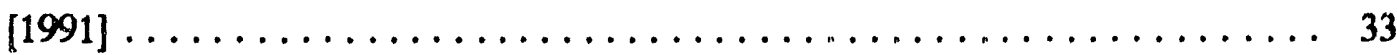

Table 15. Selected Characteristics for the Fleet's Most Important Vehicle Types -

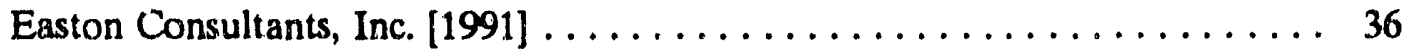

Table 16. Average Annual/Daily Vehicle Miles of Travel: ORNL/DOE Study. . . . . . . 38

Table 17. The Type of Areas Where Vehicles Were Operated: ORNL/DOE study . . . . . 38

Table 18. TIUS 1987 Statistics by Fleet Size and Area of Operation. . . . . . . . . . 42

Table 19. Percentages of Fleets that Purchase Fuel in Bulk in 1991: Runzheimer . . . . . 43 


\section{LIST OF TABLES (Continued)}

Table 20. Fueling Practices of Five Business Fleet Types - Easton Consultants, Inc.

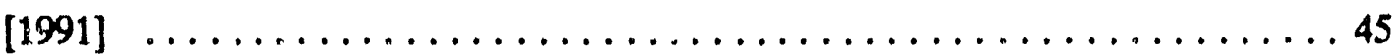

T'able 21. Alternative Fuel Vehisles by Business Type: Runzheimer ............. 46

Table 22. Types of Vehicles Operating on Alternative Fuels

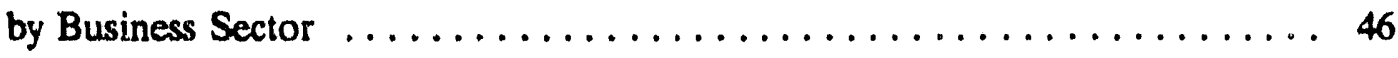

Table 23. Types of Alternative Fuels used by Business Sector $\ldots \ldots \ldots \ldots \ldots \ldots \ldots 47$

Table 24. Plan to Change the Number of Alternative Fuel Vehicles,

the Types of Alternative Fuel Vehicles in 1992: Runzheimer . . . . . . . 47

Table A-1. General Profile of the Fleet Participants: ORNL/DOE study $\ldots \ldots \ldots \ldots \ldots$ A-2

Table A-2. Vehicle Comoosition by Vehicle Type: ORNL/DOE study ............ A-5

Table A-3. The Breakouts of Fleet Trucks/Vans by Fuel Type: ORNL/DOE study ...... A-6 


\section{ACKNOWLEDGEMENTS}

This research was jointly sponsored by the Office of Transportation Technologies and Office of Policy, Planning, and Analysis of the U.S. Department of Energy (DOE). Suggestions from Barry McNutt and Phil Patterson of DOE, and Margaret Singh of Argonne National Laboratory at the various stages of this study are gratefully acknowledged. Our colleagues Stacy Davis and Jerry Hadder have helped review the original manuscript of this report. Dave Merrificld and Ralph Witte at Environmental Protection Agency, Michigan, Tom Bellamy at GE Capital Fleet Services, and Jeanne De Cervens at PHH Corporation have participated in the information gathering efforts of this study. Their skills and willingness to help have greatly expedited the information gathering process. Finally, and most importantly, our appreciation goes to those fleet managers who have taken part in the process. 


\begin{abstract}
As fleets become a larger proportion of the new vehicle population on the road, they have more influence on the characteristics of the total U.S. motor vehicle population. One of the characteristics which fleets are expected to have the most influence on is the overall vehicle fuel economy. In addition, because of the relatively large market share and the high turnover rate of fleet vehicles, fleets have been considered as a useful initial market for alternative fuel vehicles. In order to analyze fleet market potential and likely market penetration of alternative fuel vehicles and to assess infrastructure requirements for successful operations of these vehicles in the future, information on fleet sizes and composition, fleet vehicle operating characteristics (such as daily/annual miles of travel), fuel efficiency, and refueling practices, is essential. The purpose of this report is to gather and summarize information from the latest data sources available pertaining to fleet vehicles in the U.S. This report presents fleet vehicle data on composition, operating characteristics, and fueling practices. The questions these data are intended to address include: (1) How are fleet vehicles operated? (2) Where are they located? and (3) What are their usual fueling practices? Since a limited number of aiternative fuel fleet vehicles are already in use, data on these vehicles are also included in this report.
\end{abstract}




\subsection{INTRODUCTION}

Although improvements in fuel efficiency have made an important contribution to energy conservation within the transportation sector, the overwhelming reliance on petroleum for meeting this sector's demands continues to make it vuinerable to oil price shocks. The U.S. dependence on the Organization of Petroleum Exporting Countries (OPEC) has risen from 11.6\% in 1985 to $25.2 \%$ in 1990. This along with the wake of the recent Persian Gulf crisis and the widespread public concern over environmental degradation caused by heavy consumption of petroleum based fuels has led to heightened interest in the use of alternative fuels in the transportation sector.

Fleet cars acrount for a large share of the total new car sales every year, and this share has grown over the past 25 years: $8.9 \%$ in $1966,12.0 \%$ in $1970,13.8 \%$ in 1980 , and $23.7 \%$ in 1990 [Motor Vehicle Manufacturers Association, annual; Bobit Publishing Company, annual]. In contrast to the total retail sales of new cars, which has stayed at a constant level of 10 million per year over the last two decades, the sale of new fleet cars has been growing at an unprecedented rate of $6.6 \%$ per year in the last 10 years. Another important observation is that fleet vehicles have higher turnover rates than the rest of the vehicle population. For example, fleet cars are typically kept for about 3.3 years (40 months) and then sold in retail markets [NAFA, 1991; Runzheimer International, 1991]. A typical U.S. passenger car, on the other hand, has a median age of 7.8 years and a lifetime of 11.8 years [MVMA, 1991; Davis and $\mathrm{Hu}, 1991$ ]. This suggests that fleet cars are purchased at a faster rate than cars in general. Therefore, the changes in new cars, such as fuel economy and alternative fuel capability, can be introduced to the general public more rapidly through fleet vehicle markets than through non-fleet vehicle markets.

As fleets become a larger proportion of the new vehicle population on the road, they have more influence on the characteristics of the total U.S. motor vehicle population. One of the characteristics which fleets are expected to have the most influence on is the overall vehicle fuel economy [Shonka, 1978]. Because of the relatively large market share and the high turnover rates, fleets have long been considered a potential initial market for alternative fuel vehicles. However, under the current technology, alternative fuel vehicles are still limited in performance characteristics such as range, payload, speed, and acceleration, when compared to gasoline-powered vehicles. In addition, the current infrastructures for providing alternative fuels and re'ated services have not yet been fully developed. Therefore, the usage of alternative fuel vehicles in the near future may be limited. 
It is precisely these limitations that led most of the studies to conclude that the fleet market is relatively more attractive for new technologies than the retail market. The conclusion is based on the following [Shonka, 1978; Wagner, 1979]:

1. Organizational resources, both managerial and monetary, which permit the fleet operators to accept some of the risk associated with the testing of new technologies;

2. Bulk buying practices, which enable an auto manufacturer to focus its operations on a limited number of products and a small number of customers;

3. Ability to assign certain vehicles with limited performance characteristics to lessdemanding vehicle missions;

4. Conscientious maintenance and record-keeping practices; and

5. Fast mileage accumulation, which allows an auto manufacturer to quickly acquire a large amount of operational data about a particular design of alternative fuel vehicles.

In order to (1) determine the feasibility and practicality of introducing alternative fuel vehicles into the fleet market, (2) analyze potential penetration of alternative fuel vehicles in fleet vehicle markets, and (3) establish infrastructure requirements for successful operations of alternative fuel vehicles in the future, information on fleet sizes and vehicle compositions, fleet vehicle operating characteristics, such as daily/annual vehicle miles of travel, fuel efficiency, and refueling practices, is essential.

No comprehensive nationwide fleet vehicle survey is currently available. Many studies have explored the fleet market potential for different types of alternative fuel vehicles, such as electric vehicles (EVs) [e.g., Shonka, 1980; Bevilacqua-Knight, Inc., 1987; Berg, et al., 1984], natural gas based vehicles [Biederman and Blazek, 1990; Marshment, 1991; Easton Consultants, 1991], and methanolpowered vehicles [Wachs and Levine, 1985]. However, the focus and the scope of these studies were often different. These studies together with several regularly published fleet publications, such as the Automotive Fleet by Bobit Publishing Company, fleet surveys conducted by National Association of Fleet Administration (NAFA), and the Runzheimer Survey \& Analysis of Business Car Policies \& Costs by Runzheimer International, provide limited and often not comparable information on fleets.

The purpose of this study is to summarize information about fleet vehicles in the U.S. by using the existing data sources and by conducting a small scale information gathering effort of our own. Data included in this study focus on fleet vehicle composition, operating characteristics, and fueling practices. The specific questions these data are intended to address include: (1) How are fleet vehicles operated? (2) Where are they located? and (3) What are their usual fueling practices? Overall, this report will cover several major areas pertaining to fleet vehicles in the U.S.: 
1. Available data sources.

2. Fleet stock composition and historical trends by vehicle size and business type.

3. Fleet operating characteristics, such as vehicle age, expected lifetime, turnover rate, vehicle disposal, fleet size, vehicle purchase decision factors, vehicie miles of travel, and garage locations.

4. Comparisons of fleet usage by business sector, such as business, utility, or government. 5. Fueling practices.

This report also presents limited data on alternative fuel fleet vehicles already in use.

Chapter 2 provides a brief discussion of fleet definitions. Chapter 3 gives an overview of the data sources used in this study. Chapter 4 presents information on fleet vehicle composition and historical trends. Chapter 5 describes fleet vehicle operating characteristics. Chapter 6 summarizes fueling prictices of fleets in general and the type and size of alternative fuel vehicles currently used by fleet operators. Chapter 7 suggests future data needs. 


\section{FLEET DEFINITIONS}

The definition of a fleet is not consistent within the fleet industry. Shonka [1978] gave a fairly comprehensive review of the possible discrepancies among different fleet definitions. A discussion on fleet definitions which basically follow that of Shonka [1978] is included in this chapter.

Ideally, a fleet is defined as a group of vehicles, including cars, vans, station wagons, buses, and trucks, operated under a corporation or an institution (i.e., under a unified control) for nonpersonal activities. Several important features that may help to distinguish fleet vehicles from non-fleet vehicles (owned by households or individuals) are that (1) these vehicles are typically purchased in bulk, (2) vehicles are used for non-personal use during business hours, and (3) in some instances, such vehicles are engaged in pick-up and delivery activities along a fixed or predictable route and are often operated under frequent stop-and-go conditions.

Much of the discrepancy in the fleet definition lies in a distinction between what number constitutes a fleet (e.g., 4 vehicles vs. 10 vehicles), as well as whether vehicles are purchased in bulk or whether they are operated under a central control. Typically, a cutoff point of 10 vehicles is used in the fleet industry. For example, statistics on fleet cars published by Bobit Publishing Company are based on those cars which are operated in groups of ten or more. However, this definition does not require that these cars be purchased in a bulk of 10 or more. On the other hand, R.L. Polk and Company dealt with new fleet registrations only. They classify a vehicle as a member of a fleet only if it is sold to a customer who buys ten or more vehicles within a two-year period [Shonka, 1978]. The rationale favoring a cutoff at $\mathbf{1 0}$ vehicles or more is that this would allow a definite distinction between vehicles purchased for personal and non-personal uses, since an individual or household is very unlikely to own more than 10 vehicles [Shonka, 1978].

There is also some confusion as to whether a fleet must be homogeneous in vehicle type or whether it may consist of a mixture of different types of vehicles (i.e., passenger cars, vans, buses, or trucks). Since the major distinction between fleet and non-fleet vehicles is their usage (i.e., personal vs. non-personal use), it is not critical to require a fleet to be comprised of homogeneous vehicles. 
A tleet vehicle may be leased, rented, or privately owned by either an individual or an institution (business, utilities, or government). The types of fleet operations that are most commonly used in the fleet industry are as follows [Bobit Publishing Company, annual]:

1. Business/corporate - including company or salesman owned or leased;

2. Government;

3. Utilities;

4. Police;

5. Taxi;

6. Daily rental - defined as transit, daily, weekly, or monthly use of cars or trucks, generally for less than one year, including such firms as Hertz, Avis, Budget, and National;

7. Driver school - was combined with business fleets after 1983; and

8. Individual leasing company - purchased in mass by a leasing agent and are then leased to individuals or companies (from 1 to 9 vehicles).

Due to the discrepancies in fleet definition, one is, therefore, advised to be cautious when comparing statistics from different sources. 


\subsection{DATA SOURCES}

\subsection{OVERVIEW}

Data on fleets are available from several sources. This study used the latest data available. The focus of most data sources is on fleet cars, although some include limited information on fleet buses, vans, and trucks. Different data sources are usually prepared for very different purposes. Consequently, each data source has its own scope in terms of the data collection method, target population, data items collected, level of data aggregation, and data validation procedures. Different objectives frequently result in incomparable data sources.

The following is an overview of the data sources considered in this study.

1. Federal Motor Vehicle Fleet Report, by the U.S. General Services Administration (GSA) [1990].

The Federal Motor Vehicle Fleet Report summarizes data on motor fuel consumption, vehicle miles of travel, and vehicle stock for Federal owned or leased vehicles. The data are provided to the GSA by individual Federal agencies for each fiscal year.

2. Truck Inventory and Use Survey (TIUS), by the U.S. Drpartment of Commerce, Bureau of the Census [every 5 years, e.g., 1977, 1982, 1987].

TIUS provides data on the physical and operational characteristics of the Nation's truck population. The survey is conducted every 5 years for the years ending in 2 and 7 . Information is available by truck fleet size category, e.g., 1, 2-5, 6-19, etc. Truck fleet size is, however, based on the number of trucks operated by a truck owner and stationed at the same "base of operation" for the entire sample year. In other words, the fleet is an operational unit and might be smaller than the total fleet that a business entity has, if it operates from more than one base. Therefore, this survey only provides information on fleet vehicles that are operated from the same base.

3. NAFA's Used Vehicle Marketing Survey (NAFA-UVMS) and NAFA's New Vehicle Acquisition Survey (NAFA-NVAS), published in NAFA Fleet Executive, by the National Association of Fleet Administration (NAFA), Inc. [1991].

NAFA publishes a monthly bulletin for its members of fleet administrators in the U.S. and Canada. NAFA's membership covers business fleets, as well as utility and government lleets. Each year NAFA conducts a used vehicle marketing survey and a new car acquisition survey among the NAFA member fleets. The used vehicle marketing survey contains questions on the types of vehicles sold, vehicle replacement and disposal policies, and selling procedures and prices. The new vehicle acquisition survey explores NAFA member fleets' policies and practices regarding the purchase of new fleet vehicles. Questions include the number and the types of vehicles to be purchased or leased.

NAFA's 1990 Used Vehicle Marketing Survey received a total of 163 responses from the U.S. (133) and Canada (30) fleet executives who administered over 131,000 vehicles. The survey 
results were summarized in the 1991 January issue of NAFA Fleet Executive. The 1991 Model Year New Vehicle Acquisition Survey results were published in 1991 February issue of NAFA Fleet Executive. A total of 372 (U.S. 297, Canada 75) completed questionnaires were received, representing approximately $18 \%$ of the NAFA's members.

4. Runzheimer Survey \& Analysis of Business Car Folicies \& Costs: $1991-1992$ [1991], by Runzheimer International, Northbrook, Illinois 60062.

Runzheimer's Survey \& Analysis provides dula biannually on policies and costs of U.S. and Canadian business, utility, anci government fleets. The latest survey (1991) contained nearly 250 questions about fleet management, administration, and vehicles.

5. Automotive Fleet: Fact Book, published annually by Bobit Publishing Company.

The lact $300 \mathrm{k}$ contains statistics on fleet operations as estimated by the Automotive Fleet Research Department of the umpany, as well as the used-car data from NAFA's surveys.

6. Oklahoma Large Fleet Survey (OI.FS), by the Mivision of Regional and City Planning, University of Oklahoma [Marshment, 1991].

This survey collected data on fuel consumption and travel characteristics from large fleet operators, operating 25 or more vehicles, within the State of Oklahoma. It is a one-time survey of 18 flest operators conducted in 1989 . The purpose of his study was to determine the feasibility and practicality of introducing natural gas based alternative fue's into the fleet vehicle market.

7. Vehicle Fleets Survey in the South Coast Air Basin (VFS-SCAB), by tide Urban Innovations Group for the South Coast Air Quality Managemen! District [Wachs and Levine, 1985].

Urban Innovations Group conducted a one-time survey for the South Coast Air Quality Management District in California to determine the potential for methanol fuel use by lightand heavy-duty vehicles in the South Coast Air Basin (SCAB). Separate questionnaires were used for transit and non-transit fleets. Data were collected on fleet size, garage locations, age distribution of the vehicles, typical fleet vehicle lifetime in years and vehicle miles of travel, fuel consumption, and plans and criteria for acquisition of new vehicles.

8. Commercial Fleet Manager's Survey (CFMS) by the University of Michigan for the Electric Power Research Institute and Detroit Edison Company [Berg et al., 1984].

This survey was conducted for a study called Electric Vehicles in Commercial Sector Applications. The study dealt with fleets of light-duty vehicles. The purpose of this study was to investigate the potential for electric vehicles (EVs). Due to the limited operating ranges of EVs, the questionnaire was designed to focus on vehicle travel requirements, cost and range tradeoffs, and operational practices. Fleet managers in establisisments throughout the U.S. were contacted by telephone and 583 interviews in total were conducted during the fall of 1983 . The overall response rate for these interviews was $92 \%$.

9. A survey conducted for a study titled Economic Analysis of Low-Pressure Natural Gas Vehicle Storage Technology by the Institute of Gas Technology (IGT) for the Gas Research Institute [1990]. 
The objective of this work was to evaluate the technical requirements and economic implications of using a natural gas system for application in fleet vehicles. Vehicle categories included in the study were: pickup trucks, vans, deliv . y step vans, and buses. These vehicles have been identified as promising candidates for dedicated compressed natural gas (CNG) and adsorbed natural gas (ANG) fleet application: because they are primarily refueled at a central location, serve a regular route with predictable daily mileage, and have large cargo areas that can accommodate fuel storage tanks. One fleet operator from each vehicle category was interviewed on such factors as fleet size, daily driving range, vehicle fuel efficieñy, and required fueling times. Fleet market data used in this study were taken from NAFA's and other surveys.

10. Natural Gas Vericle Fleet Market Study by Easton Consultants, Inc. for the American Gas Association and NGV Coalition (AGANNGV) [1991].

The objective of this study was to determine key fleet market characteristics and requirements for natural gas vehicies' (NGVs) success. The report focuses on the information gained in a telephone survey among 500 randomly selected fleet managers in five businese categories: transit. bus fleets, school bus fleets, taxi/limo fleets, service/heavy delivery fleets, and repair service fleets. The sample was drawn from 31 metropolitan or consolidated metropolitan areas. The interviews were conducted during December 1990 and January 1991.

11. Information collection effort by Oak Ridge National Laboratory (ORNL') for the U.S. Department of Energy (ORNL/DOE study).

The information was collected via a discussion guide. Both phone and mailout contacts were used. Only a selected number of fleet operators was contacted during October-December, 1991. The main purpose of this effort was to provide supplementary information on vehicle miles of travel, fleet vehicles' garage locations (central business district, suburban, small city, or rural area), and fueling practices. The data were collected from three major fleet sectors: business, utility, and government, and by four vehicle types: cars, light trucks (and vans), medium trucks, and heavy trucks. The focus was on fleets with 10 or more vehicles. Thirtythree fleets in total participated in this information gathering effort: 21 business ( 2 overnight delivery service and 19 service/retail) fleets, 5 utility fleets, and 7 government (4 State and 3 municipal) fleets. There fleets operate over 162,000 vehicles. The general profile of these fleet participants and major findings of this study are presented in Appendix $\mathbf{A}$. Since these fleet operators were not selected statistically, the results from this effort should not be used to make inferences of the entire fleet vehicle population. 


\subsection{DATA COLLECTION METHOD}

Except GSA and Bobit, which were total reporting (censuses), the data sources considered were obtained through sampling methods. The data collected in most data sources were, however, not based on a statistically designed probability sample and, therefore, have to be carefully interpreted. Table 1 includes fleet definition, sampling method, types of fleets included, and sample size used in these studies. 


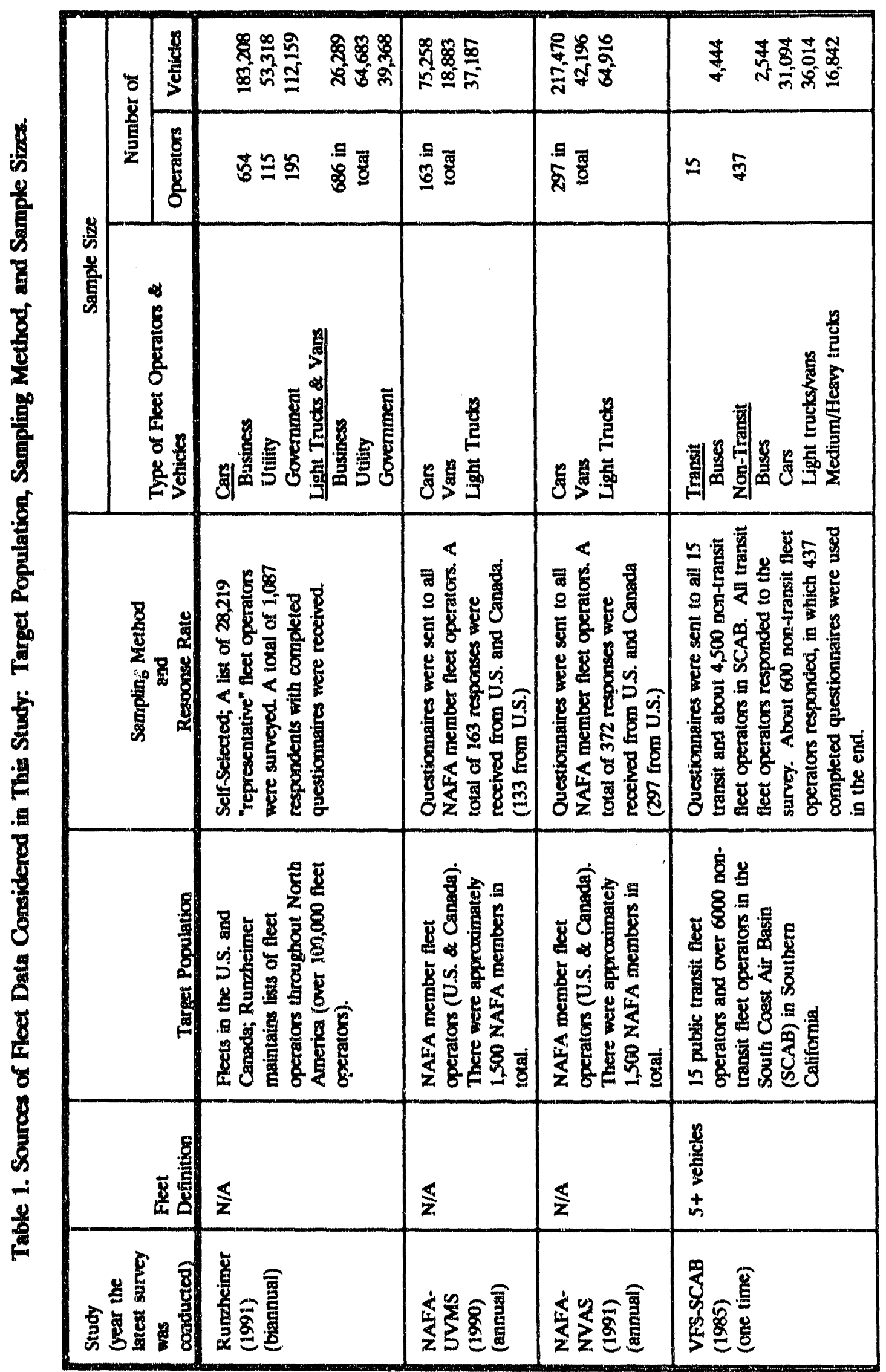


Table 1. (Continued)

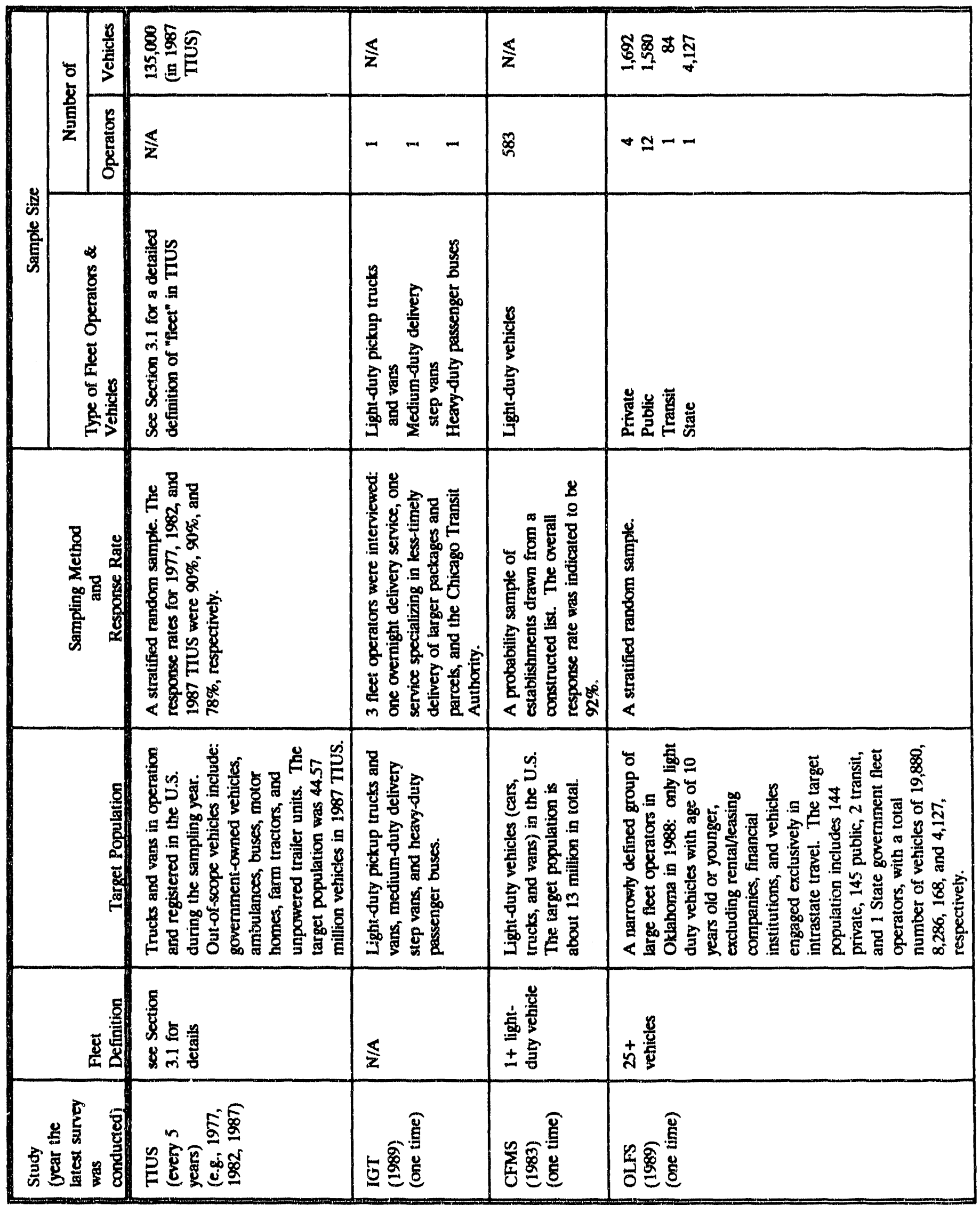


Table 1. (Continued)

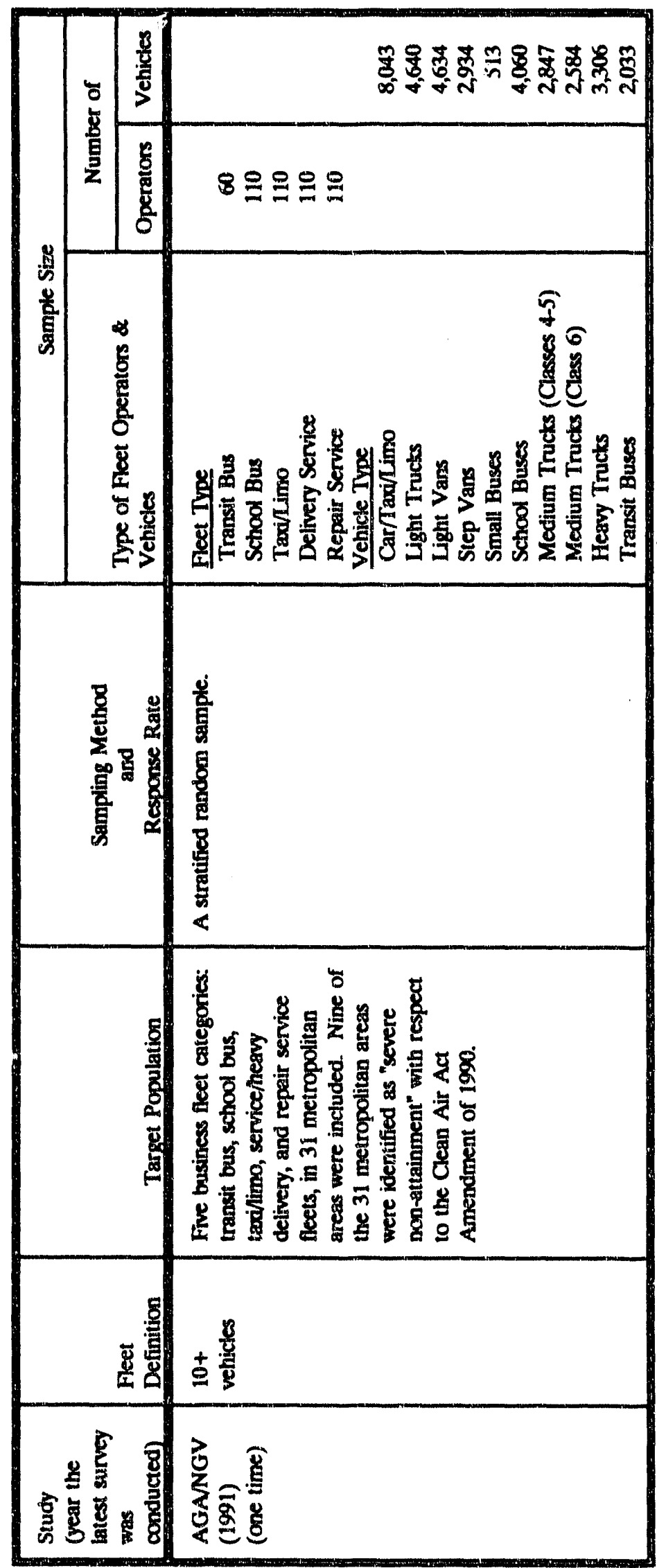

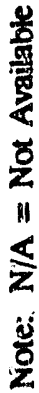




\subsection{VEHICLE COMPOSITION}

\subsection{HISTORICAL TRENDS}

Although fleet cars constitute only a small fraction (5.8\%) of the total passenger car registrations, the fleet share of new car sales accounts for a large percentage of the total new car sales every year. This share has grown over the past 25 years: $8.9 \%$ in 1966, 12.0\% in 1970, 13.8\% in 1980, and $23.7 \%$ in 1990 (Table 2). In contrast to the total retail sale of new cars, which has stayed at a constant level of 10 million per year over the last two decades, the sale of new fleet cars has been growing at an unprecedented rate of $6.6 \%$ per year in the last 10 years (Table 2).

Table 3 shows the size of car fleets from 1966 to 1990 by the eight business categories classified in Chapter 2. Business fleets continue to dominate the fleet vehicle stock: $46 \%$ in 1990, followed by individual leasing companies $(24.3 \%)$ and daily rentals $(11.9 \%)$. The fastest growing business categories in the last 25 years were daily rentals and individually leased vehicles. Daily rentals have grown at a steady average annual growth rate (AAGR) over the years: $5.0 \%$ from 1971 to 1980 and $4.5 \%$ from 1984 to 1990 . Individually leased vehicles grew at an AAGR of about $10 \%$ from 1966 to 1980; this growth has, however, dropped significantly in the last 10 years, with an AAGR of only $1.8 \%$. In the last 15 years, business fleets have grown at a modest AAGR of less than $1.7 \%$, with utility fleets staying at roughly the same size, while government fleets have declined at an AAGR of $2.1 \%$. Within the business fleets, the number of employee-owned cars grew at an AAGR of $4.5 \%$ in the last 10 years, a much higher growth rate compared to that of company-owned and company-leased cars (about 1.2\%).

The size of government car fleets reported in Table 3 is about one-half of that reported in Highway Statistics [Federal Highway Administration (FHWA), annual]. FHWA's numbers, as shown in Table 4, suggest that there are 1.158 million publicly-owned cars, as opposed to the 0.538 million reported by Bobit Publishing Company. This discrepancy is because FHWA's "cars" include vans, station wagons, and jeep-like vehicles. FHWA's numbers indicate a slight increase of publicly-owned vehicles in recent years: $2.8 \%, 1.4 \%$, and $2.5 \%$ for cars, buses, and trucks, respectively, from 1983 to 1990. FHWA's numbers are compiled from GSA report and vehicle registration data submitted by each Stzte. Vehicle classes included in States' vehicle registration data, however, are not consistent across States. For example, some States include vehicles operated by safety departments (fire and police departments), public educational institutions, public transit authorities; while others do not. 
Table 2 U.S. Passenger Car Registrations and New Car Retail Sales: Total va. Fleet of 10 or More.

\begin{tabular}{|c|c|c|c|c|c|c|}
\hline \multirow{2}{*}{$\begin{array}{l}\text { Calendar } \\
\text { Year }\end{array}$} & \multicolumn{2}{|c|}{$\begin{array}{c}\text { Registrations } \\
\text { (in 1000's) }\end{array}$} & \multirow{2}{*}{$\begin{array}{c}\text { Fleet Share } \\
\text { of } \\
\text { Registration } \\
\text { (percent) }\end{array}$} & \multicolumn{2}{|c|}{$\begin{array}{c}\text { Retail Sales } \\
\text { (in 1000's) }\end{array}$} & \multirow{2}{*}{$\begin{array}{c}\text { Fleet Share } \\
\text { of Retail } \\
\text { Sales } \\
\text { (percent) }\end{array}$} \\
\hline & Total $^{1}$ & Fleet $^{2}$ & & Total $^{1}$ & Fleet $^{23}$ & \\
\hline $\begin{array}{l}1990 \\
1989 \\
1988 \\
1987 \\
1986\end{array}$ & $\begin{array}{l}145,010 \\
143,081 \\
141,252 \\
137,324 \\
135,431\end{array}$ & $\begin{array}{l}8,312 \\
8,318 \\
8,201 \\
7,934 \\
7,756\end{array}$ & $\begin{array}{l}5.7 \\
5.8 \\
5.8 \\
5.8 \\
5.7\end{array}$ & $\begin{array}{r}9,301 \\
9,772 \\
10,530 \\
10,277 \\
11,460\end{array}$ & $\begin{array}{l}2,201^{4} \\
2,103 \\
2,643 \\
1,837 \\
1,879\end{array}$ & $\begin{array}{l}23.7 \\
21.5 \\
19.4 \\
17.9 \\
16.4\end{array}$ \\
\hline $\begin{array}{l}1985 \\
1984 \\
1983 \\
1982 \\
1981\end{array}$ & $\begin{array}{l}131,864 \\
128,158 \\
126,444 \\
123,702 \\
123,098\end{array}$ & $\begin{array}{l}7,485 \\
7,268 \\
6,895 \\
6,820 \\
7,149\end{array}$ & $\begin{array}{l}5.7 \\
5.7 \\
5.4 \\
5.5 \\
5.8\end{array}$ & $\begin{array}{r}11,042 \\
10,390 \\
9,182 \\
7,982 \\
8,536\end{array}$ & $\begin{array}{l}1,910 \\
1,638 \\
1,301 \\
1,135 \\
1,217\end{array}$ & $\begin{array}{l}17.3 \\
15.8 \\
14.2 \\
14.2 \\
14.3\end{array}$ \\
\hline $\begin{array}{l}1980 \\
1979 \\
1978 \\
1977 \\
1976\end{array}$ & $\begin{array}{l}121,601 \\
118,429 \\
116,573 \\
112,288 \\
110,189\end{array}$ & $\begin{array}{l}7,163 \\
7,019 \\
6,876 \\
6,517 \\
6,287\end{array}$ & $\begin{array}{l}5.9 \\
5.9 \\
5.9 \\
5.8 \\
5.7\end{array}$ & $\begin{array}{r}8,979 \\
10,673 \\
11,314 \\
11,183 \\
10,110\end{array}$ & $\begin{array}{l}1,238 \\
1,361 \\
1,505 \\
1,344 \\
1,165\end{array}$ & $\begin{array}{l}13.8 \\
12.8 \\
13.3 \\
12.0 \\
11.5\end{array}$ \\
\hline $\begin{array}{l}1975 \\
1974 \\
1973 \\
1972 \\
1971\end{array}$ & $\begin{array}{c}106,706 \\
104,229 \\
101,412 \\
96,553 \\
92,221\end{array}$ & $\begin{array}{l}5,956 \\
5,836 \\
5,744 \\
5,373 \\
5,150\end{array}$ & $\begin{array}{l}5.6 \\
5.6 \\
5.7 \\
5.6 \\
5.6\end{array}$ & $\begin{array}{r}8,624 \\
8,853 \\
11,424 \\
10,940 \\
10,250\end{array}$ & $\begin{array}{c}955 \\
1,083 \\
1,291 \\
1,105 \\
1,098\end{array}$ & $\begin{array}{l}11.1 \\
12.2 \\
11.3 \\
10.1 \\
10.7\end{array}$ \\
\hline $\begin{array}{l}1970 \\
1969 \\
1968 \\
1967 \\
1966\end{array}$ & $\begin{array}{l}88,775 \\
86,414 \\
83,189 \\
79,999 \\
77,752\end{array}$ & $\begin{array}{l}5,041 \\
4,889 \\
4,548 \\
4,254 \\
4,106\end{array}$ & $\begin{array}{l}5.7 \\
5.7 \\
5.5 \\
5.3 \\
5.3\end{array}$ & $\begin{array}{l}8,405 \\
9,583 \\
9,656 \\
8,337 \\
9,028\end{array}$ & $\begin{array}{c}1,009 \\
1,093 \\
985 \\
825 \\
800\end{array}$ & $\begin{array}{r}12.0 \\
11.4 \\
10.2 \\
9.9 \\
8.9\end{array}$ \\
\hline $\begin{array}{c}\text { AAGR }(\%)^{5} \\
1966-75 \\
1971-80 \\
1976-85 \\
1981-90\end{array}$ & $\begin{array}{l}3.5 \\
3.1 \\
2.0 \\
1.8\end{array}$ & $\begin{array}{l}4.1 \\
3.7 \\
1.9 \\
1.7\end{array}$ & & $\begin{array}{l}-0.5 \\
-1.5 \\
1.0 \\
1.0\end{array}$ & $\begin{array}{l}2.0 \\
1.3 \\
5.5 \\
6.6\end{array}$ & \\
\hline
\end{tabular}

1. Source: MVMA Motor Vehicle Facts and Figures, by Motor Vehicle Manufacturer Association, annual.

2. Source: Automotive Fleet: Fact Book, by Bobit Publishing Company, annual.

3. New car fleet registrations (not actual sales).

4. November and December figures were estimated.

5. Average annual growth rate (AAGR) in percent. 


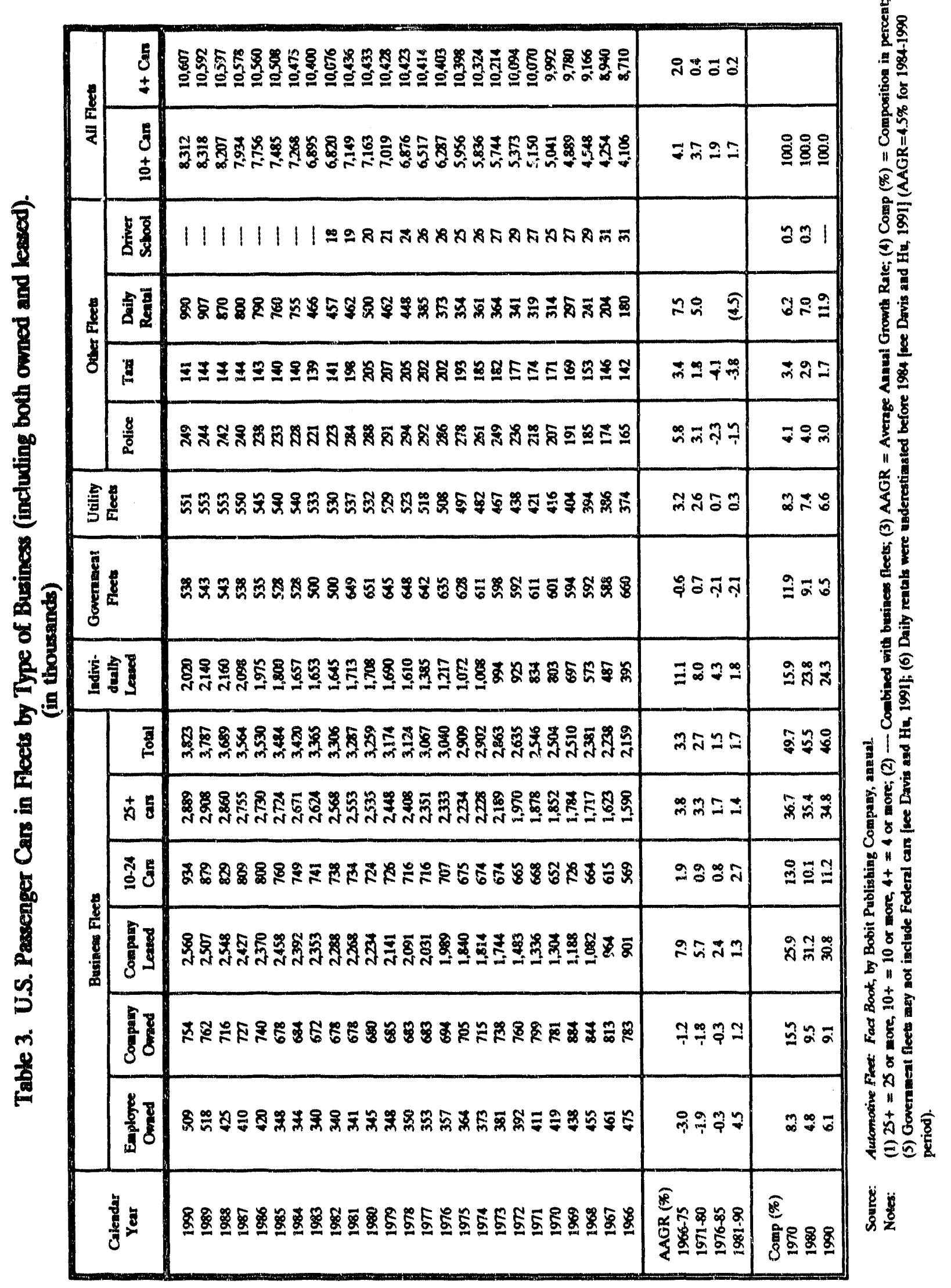




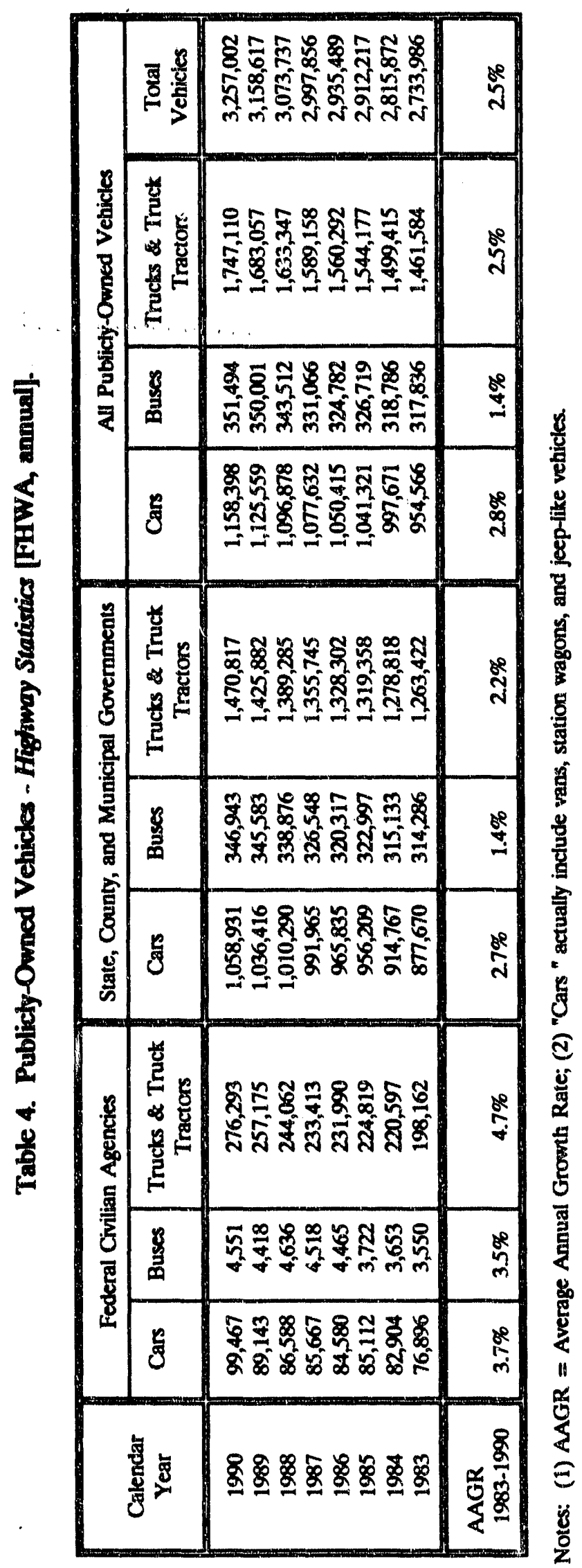




\subsection{FLEET COMPOSITION}

\subsection{Vehicle Size and Type}

Bobit's data indicated that there were about 8.312 million fleet cars, including owned and leased, in 1990: Business - 3.823 million, Government - 0.538 million, Utilities - 0.551 million, and Others -3.400 million (Table 3). Table 5 shows the composition of car fleets by size and business type in recent years as reported in Runzheimer surveys. Although subcompacts and compacts accounted for a significant share of business fleets in $1983(60 \%)$, this share decreased to $15 \%$ in 1991. The share of intermediate cars increased significantly, from $29 \%$ in 1983 to $52 \%$ in 1991. Minivans have doubled their business sector share from $4 \%$ in 1987 to $8 \%$ in 1991 .

Government fleets, including mainly State and local governments, have shown a similar decrease in compact and subcompact shares, but with a substantial increase in full-size cars. On average, government fleets have a larger share of large cars than that of the business fleets. However, Federal car fleets are dominated by subcompact and compact cars [GSA, 1990]. The number of Federal-ownud cars (sedans) comprises, however, only a fraction of the total government fleet cars. There were about 99,467 domestic sedans owned by Federal civilian agencies in fiscal year 1988 , compared to the total government-owned cars of 543,000 (Table 3).

According to Bobit's data, there were about 2.209 million fleet trucks, including light and medium trucks, in 1990: Business - 1.214 million, Government - 0.246 million, Utilities - 0.592 million, and Others - 0.157 million. (Note that the total U.S. truck registrations were 44.48 million in 1990 [FHWA, annual].) Table 6 presents the composition of light-truck and van fleets by business type from the latest Runzheimer survey. About $50 \%$ of the light-truck/van fleets are pickup trucks across all three business types. Overall, pickups and full-size vans dominate the light-truck/van fleets in all business sectors, especially, in government and utility fleets. The business sector has a relatively higher percentage of minivans in its fleet composition than the utility and government sectors do.

Table 7 compares the shares of new car registrations by car size between fleets and non-fleets [Bobit Publishing Company, annual]. No obvious changes in car-size shares of fleets can be observed, which is inconsistent with Runzheimer's data. There are at least thre possible reasons for this inconsistency: (1) Bobit's data included only a selected number of vehirle models, (2) Vehicle classification schemes were different between two sources, and (3) Runzheimer's survey was not based on a probability sample. More data will be needed to verify the findings from Runzheimer's surveys (Table 5). 


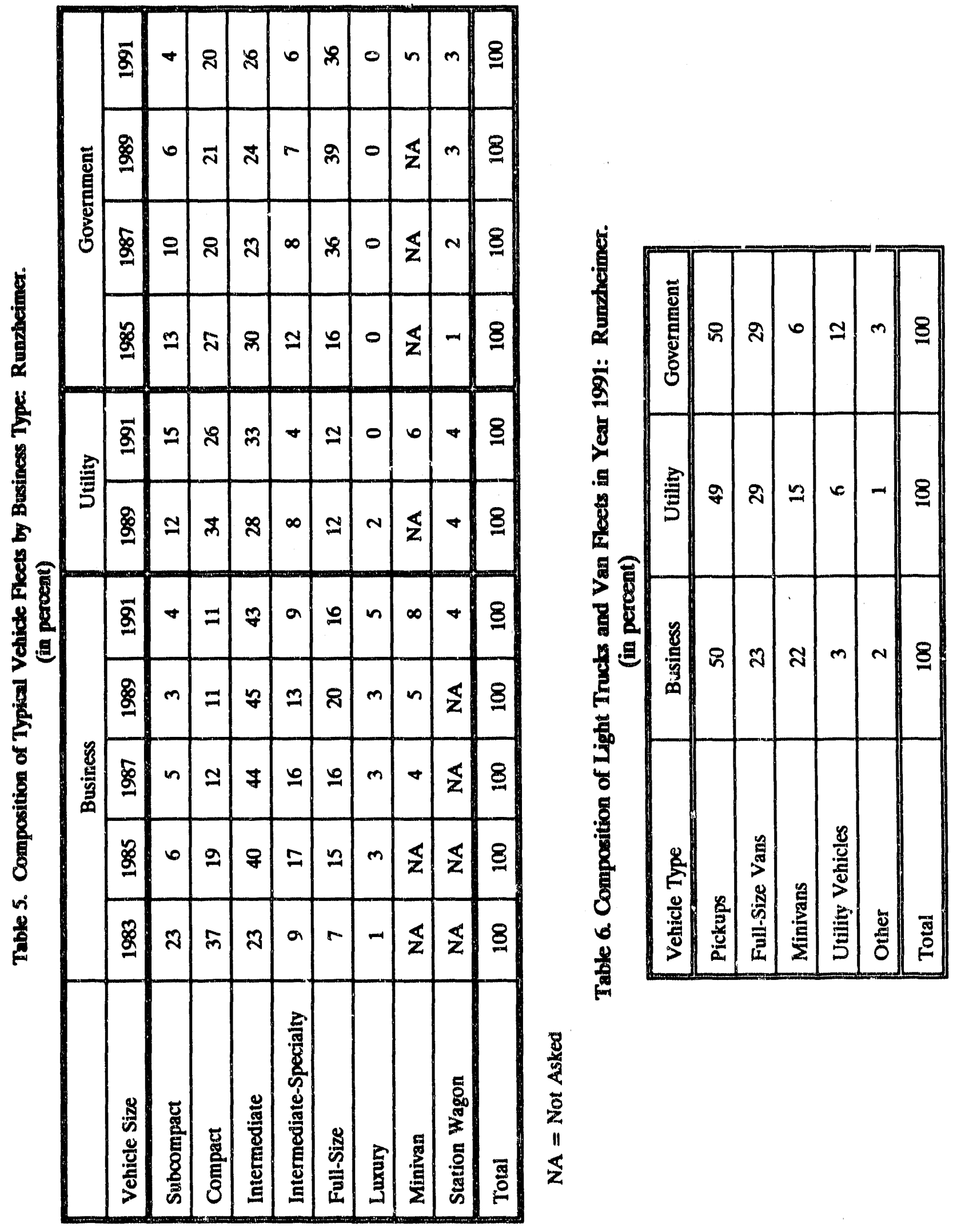




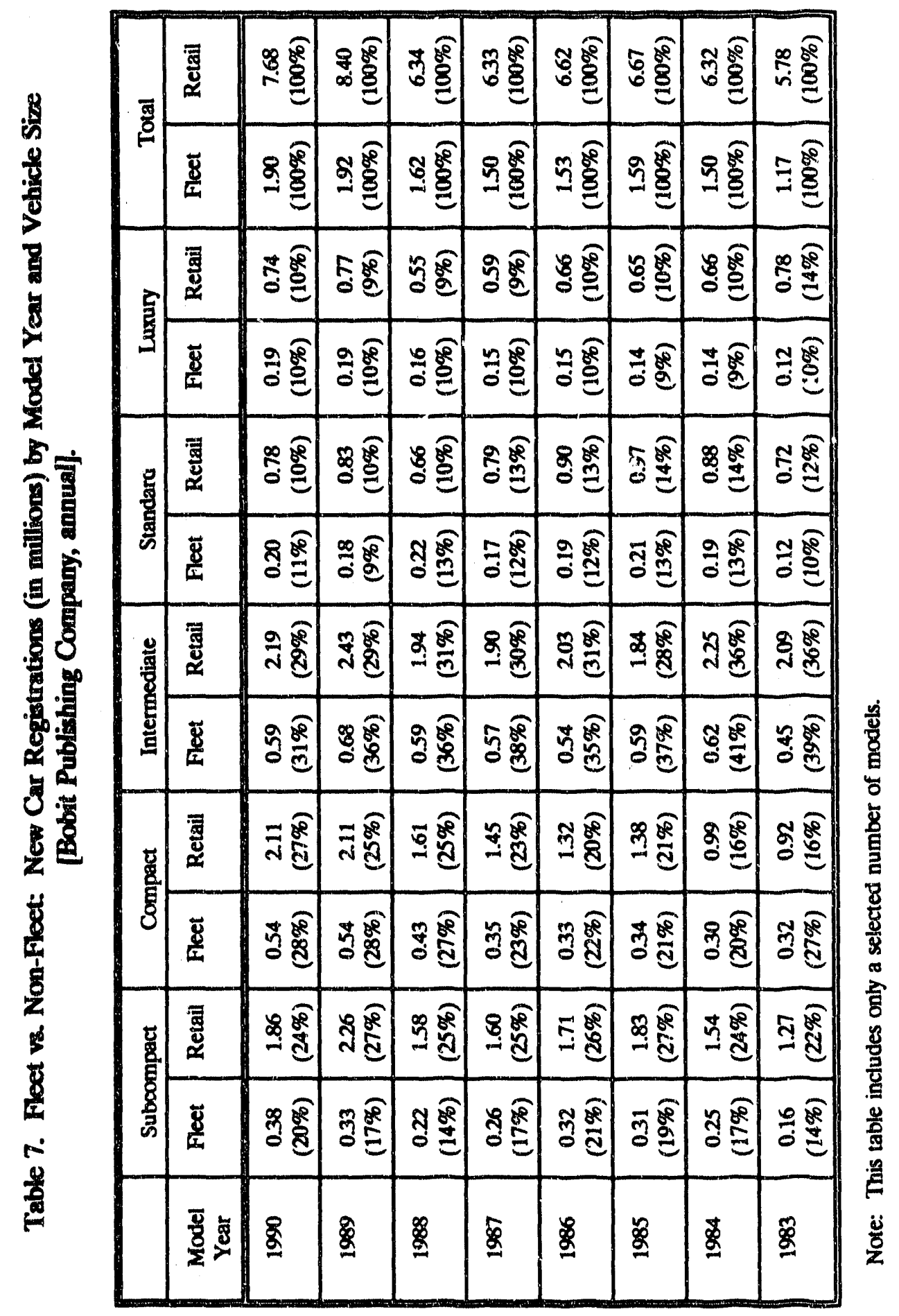


Table 8 shows a detailed breakdown of vehicle composition for five business fleet types [Easton Consultants, Inc., 1991]: transit bus, school bus, taxi/limo, service/heavy delivery, and repair service. The service/heavy delivery fleet respondents indicated that $42 \%$ of their vehicles were vans/light trucks, $28 \%$ medium trucks, and $19 \%$ heavy trucks. The majority of vehicles operated by repair service fleets are vans or light trucks (68\%).

\subsection{Vehicle Makes}

Data on detailed fleet vehicle stock by make are not available from any data sources. However, some interesting observations could be made from some of the surveys. The four most popular fleet cars in 1990, according to Runzheimer [1991], were the Buick Century, Chevrolet Lumina, Ford Taurus, and Dodge Dynasty. NAFA's new vehicle acquisition survey [1991] indicated that $39 \%$ of responding fleet managers are most likely to purchase their vehicles from FordLincoln/Mercury, 35\% from General Motors, and 2.2.3\% from Chrysler. Imports will account for only $2.7 \%$ of the purchases. Furthermore, $89 \%$ of both U.S. and Canadian fleet respondents do not buy vehicles with traditionally "foreign" nameplates. Of these, $50 \%$ in the U.S. and $68 \%$ in Canada said that they do not buy such vehicles because of a perceived "Buy North itmerican" company policy. However, only $19 \%$ of U.S. fleet managers indicated that their companies have a written "buy domestic only" policy. Fiity-two percent of the respondents indicated that they would not buy "foreign" vehicles even if they were primarily manufactured in the U.S. The Bobit data, however, did not suppori NAFA's "purchase intent" statistics. It indicated that import shares of new fleet cars were quite significant in recent years: $18.5 \%$ for $1988,24.8 \%$ for 1989 , and $15.9 \%$ for 1990 . This suggests that data from NAFA's respondent fleets may not be representative.

\subsection{Type of Business Vehicle Program}

Most business fleets used one or a combination of the following three business vehicle programs: company-owned, company-leased, or employee-provided. At this time of economic "downturn," corporations have sought ways to rein in their fleets to contain the costs of operating business. Many fleet operators use leased or employee-provided programs to protect themselves from having to dispose of used vehicles in a depressed market, and also as a hedge against the risk of acquiring a vehicle model whose resale value declines at a greater than average rate [Wagner, 1979; Runzheimer International, 1991]. Table 9 shows this trend in recent years--more corporations gave up a "company-owned only" program in favor of a combination of "company-leased" and "employee-provided" business vehicle program. 


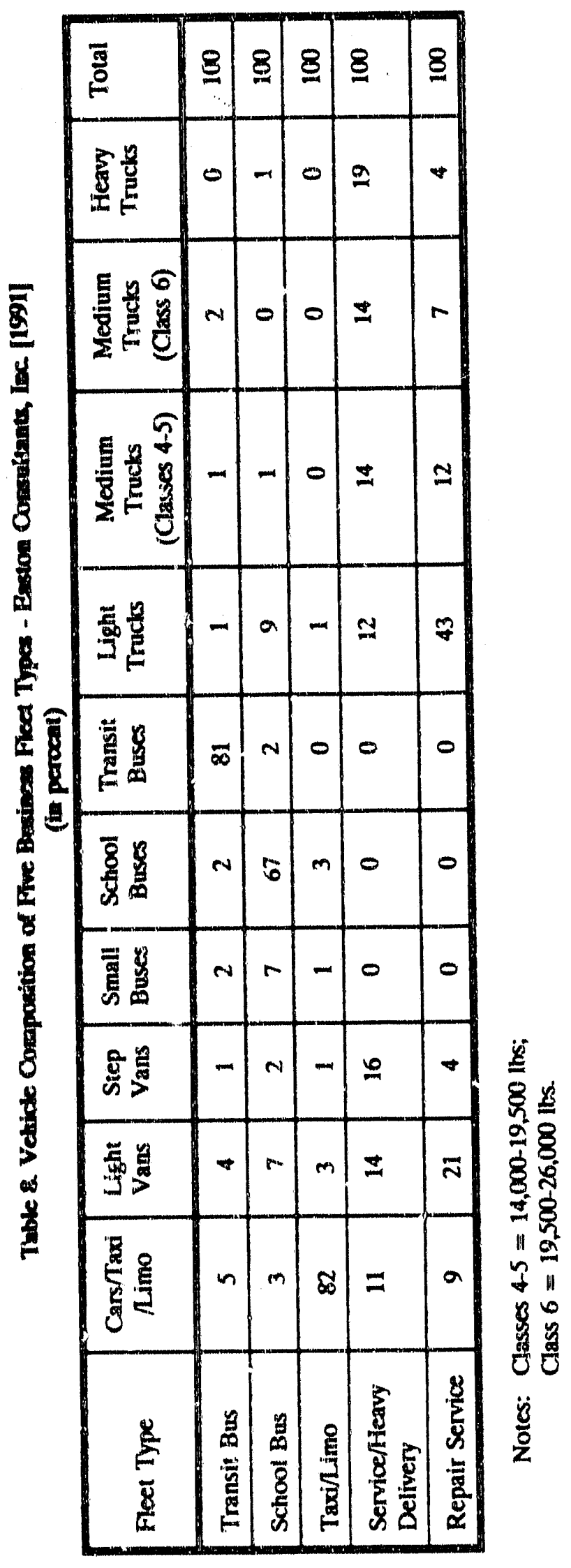




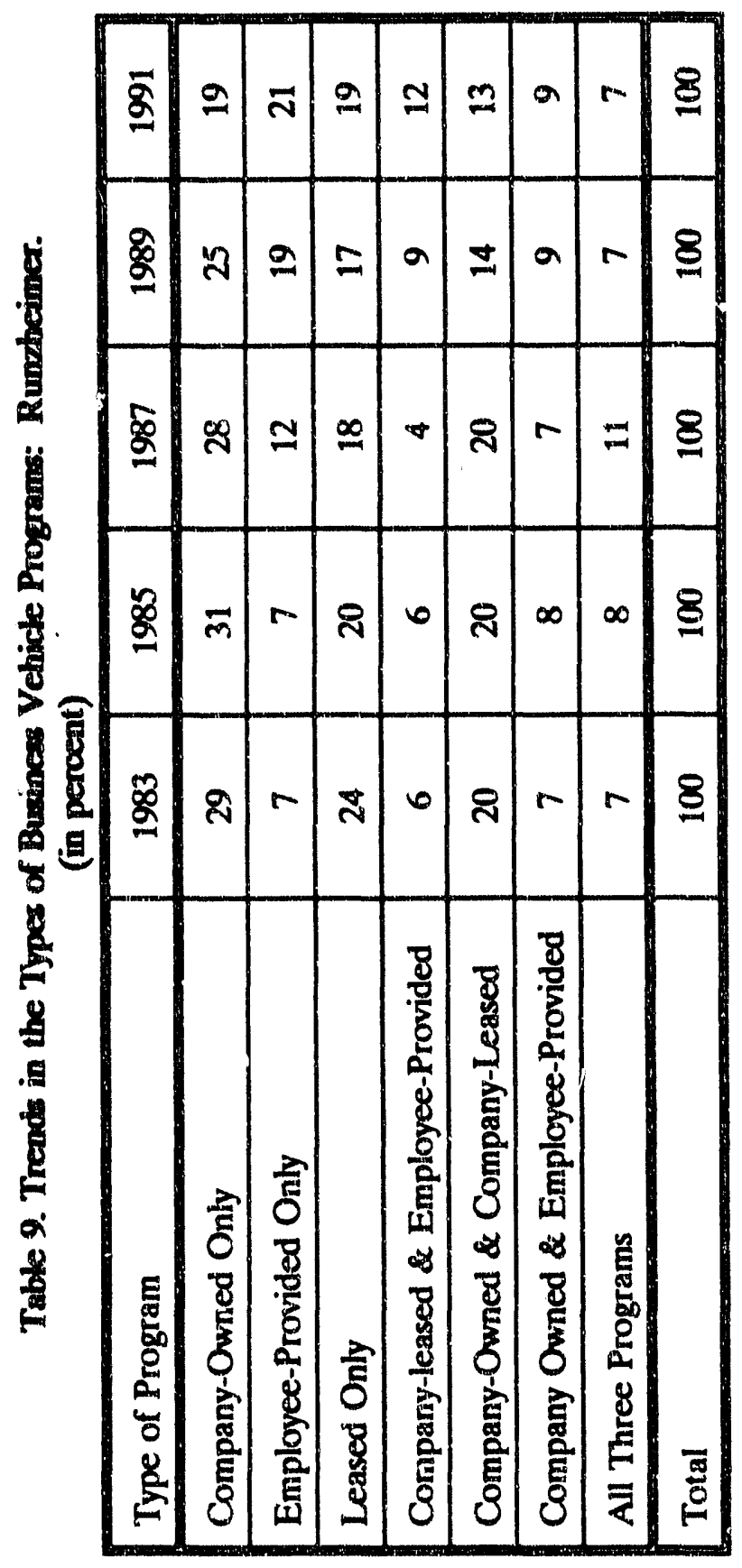


The composition of fleet vehicles by whether they are company-owned, leased, or employeeowned is also available by business type from the Automotive Fleet Fact Book [Bobit Publishing Company, annual]. Table 10 shows the percentages of passenger cars and light trucks operated for business purposes in business, utility, and government fleets. This table indicates that the percentage of company-owned fleet cars has been declining over the last few years in all business types, especially government and utility sectors. Employee-owned business cars in the business sector, on the other hand, has increased from $19.1 \%$ to $23.3 \%$. These trends, however, do not appear in light trucks. The percentage of company-owned light trucks has increased with a commensurate decrease in companyleased (or company-managed) light trucks. In contrast to the business sector, government and utility sectors usually do not depend on employee-owned vehicles.

\subsubsection{Vehicle Weight}

The data on the composition of fleet vehicles by vehicle weight are quite limited. Table 8 gives some information on truck weight for five business fleet categories. Table 11 gives a breakdown of Federal-civilian-agency in-use domestic vehicles by vehicle type. Light trucks (GVWR $\leq 8,500$ lbs) dominate the Federal government fleets $(63.8 \%)$.

The ORNL/DOE study suggests that, except for delivery and transportation service fleets, most of the business fleets operate mainly passenger cars, with a small number of light trucks and vans. Delivery and transportation service fleets, on the other hand, operate a significant proportion of light and medium trucks in their fleet. Out of the 72,450 vehicles operated by the largest overnight delivery service company, $8.4 \%$ are light trucks/vans, $79.0 \%$ medium trucks, and $12.6 \%$ heavy trucks. However, the distribution for the second largest delivery service is very different -68.9\% light trucks/vans, $20.9 \%$ medium trucks, and $10.0 \%$ heavy trucks. For the five utility fleets examined in the ORNL/DOE study, $39.0 \%$ are light trucks, $15.0 \%$ medium trucks, and $23.4 \%$ heavy trucks. 


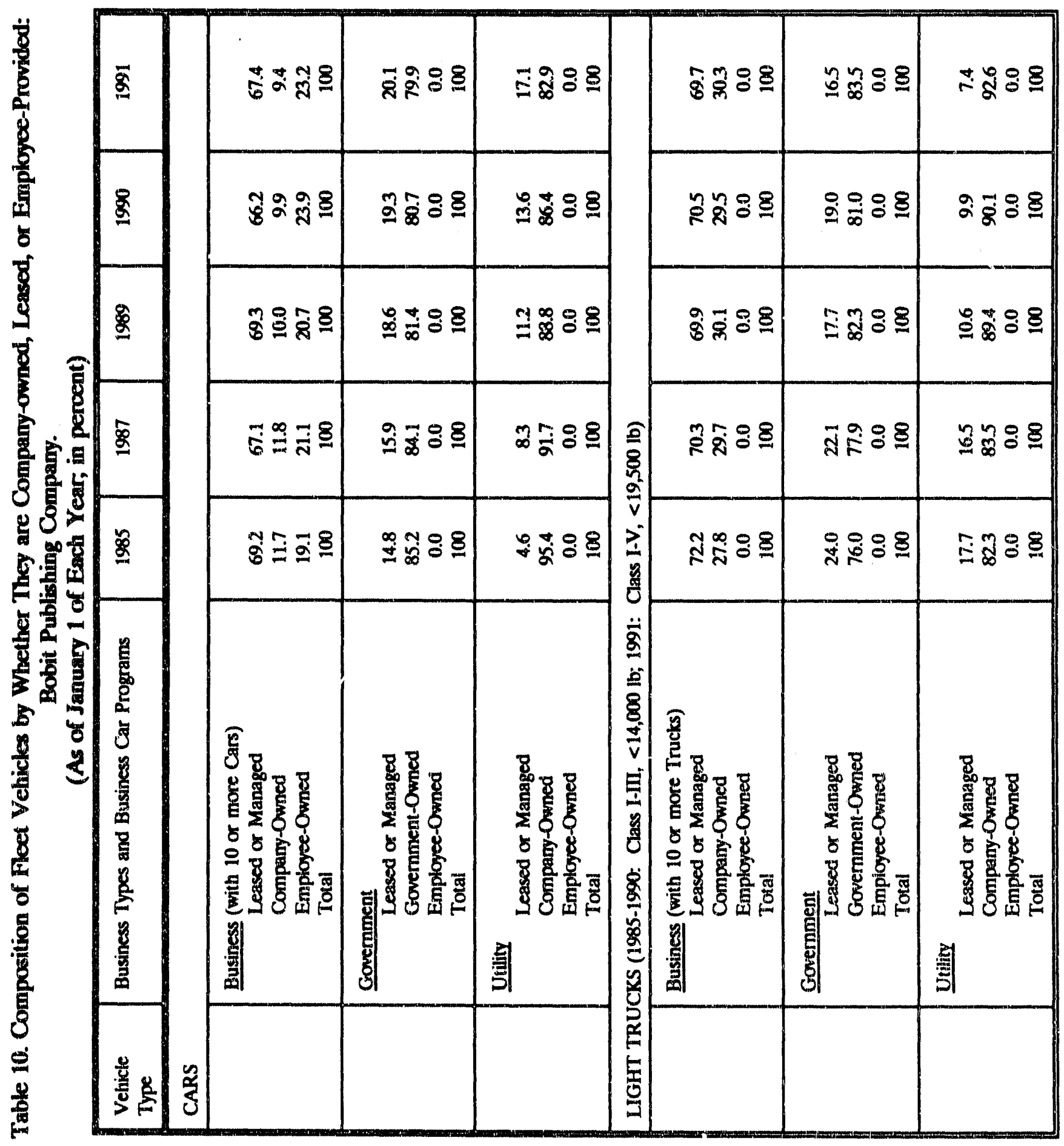




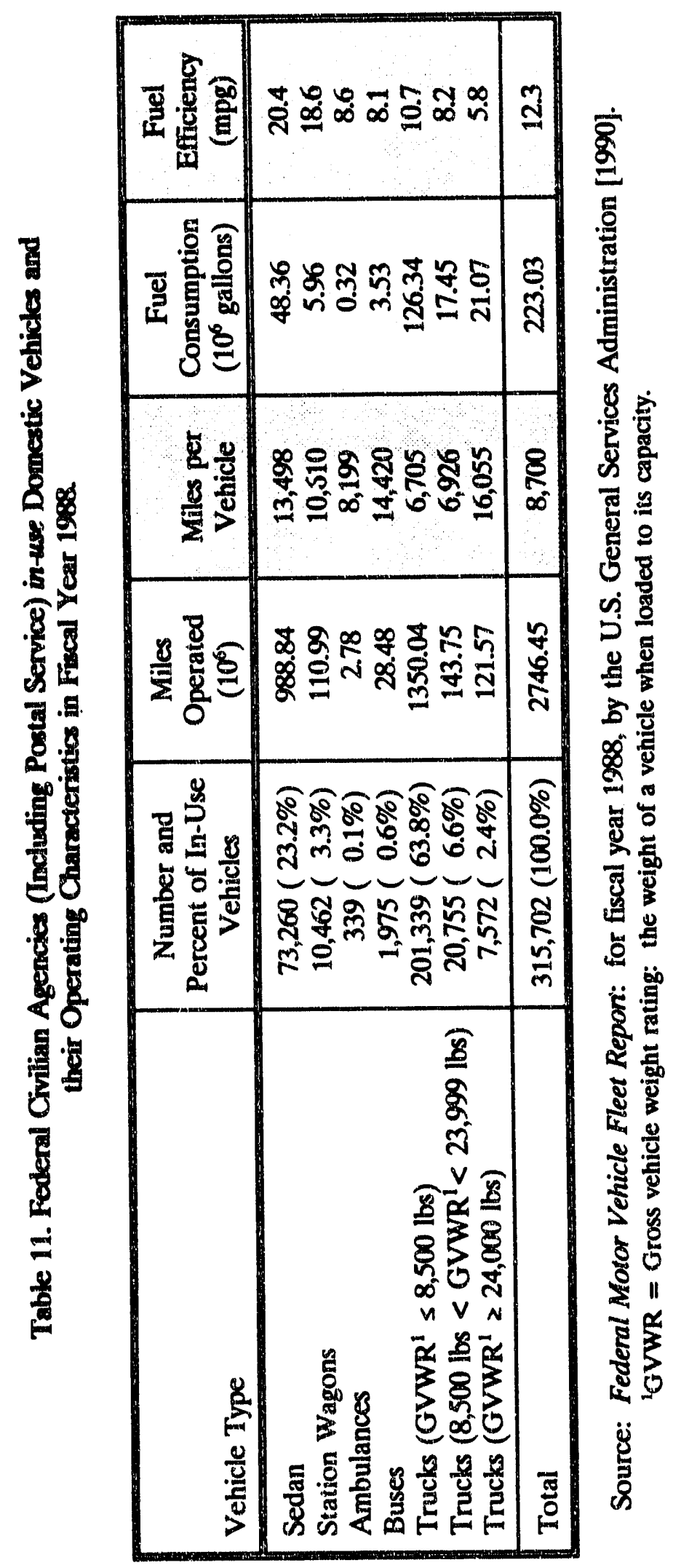




\subsection{OPERATING CHARACTERISTICS}

\subsection{VEHICLE AGE, REPLACEMENT PLANS, AND PURCHASE DECISIONS}

NAFA's latest survey (NAFA-UVMS) indicated that: Cars are usually kept for 40 months or operated for 73,980 miles and then sold in the retail market, Vans 56 months or 73,120 miles, Light Duty Trucks 68 months or $\mathbf{7 2 , 4 8 3}$ miles. Results from Runzheimer survey also showed that passenger cars were kept for 38 months or operated for 67,648 miles. A typical U.S. passenger car, on the other hand, has a median age of 7.8 years (93.6 months) and a lifetime of 11.8 years (141.6 months) [MVMA, 1991; Davis and Hu, 1991]. This suggests that fleet cars are purchased at a faster rate than cars in general. Therefore, the changes in new cars, such as fuel economy and alternative fuel capability, can be introduced more rapidly through fleet vehicle markets than through non-fleet vehicle markets. Runzheimer's survey also indicated that the predominant measure to cope with economic hardship by executives responsible for business, government, and utility fleets is to lengthen replacement cycles and tighten operating expense controls. A 1988 survey conducted by the National Conference of State Fleet Administrators (NCSFA) suggested that the replacement policy of State government fleets varies from State to State, with a typical range of 5 to 7 years or 75,000 to 100,000 miles [personal communication with staff members of NCSFA, 1992].

Table 12 shows statistics from the ORNL/DOE study on how long a typical fleet vehicle is kept before it is sold to cthers. These statistics are presented by both vehicle type and business type. Government and utility sectors tend to keep their passenger cars longer (68 and 81 months) than those operated by business sector ( 35 months). The heavier the vehicles, the longer they are kept. Heavy trucks are kept for about 8.5-11 years, while light trucks are kept for about 4.5-7 years. However, the statistics presented by the ORNL/DOE study are not conclusive since only 21 business, 5 utility, and 7 govern ment fleets are included.

The estimat $d$ average lifetime of a vehicle was reported in VFS-SCAB as: public transit (bus), 11.2 years/585,000 miles, non-transit vehicles operated by public agencies, 11 years $/ 109,000$ miles, and non-transit vehicles operated by private organizations, 8 years $/ 210,000$ miles. Non-transit vehicles include both passenger cars, vans, buses, and trucks. 
Table 12. The Average Length of Time Vehicies are Kept Before Sold to Others:

ORNLIDOE study.

(in months)

\begin{tabular}{|l|c|c|c|}
\hline & Business & Utility & Government \\
\hline Cars & 35 & 68 & 81 \\
\hline Light Trucks & 56 & 60 & 82 \\
\hline Medium Trucks & 83 & 86 & 96 \\
\hline Heavy Trucks & 103 & 132 & 117 \\
\hline
\end{tabular}

The business fleet operators in Runzheimer's survey responded that the most financially rewarding method of disposal is selling a used fleet car to an employee, followed by selling directly to the public, and last returning to lessor. The government fleets, on the other hand, chose auction (81\%), trade-in (7\%), and sealed bids (7\%); and utility fleets selected auction (62\%), trade-in (16\%), and sell to employee (9\%) as the most commonly used methods. NAFA's 1990 used vehicle marketing survey suggested that most fleet vehicles were disposed at auctions (cars: $53 \%$ and vans/light trucks: $45.54 \%$ ), followed by selling to employees (cars: $24 \%$, vans/light trucks: $25.8 \%$ ) and returning to wholesaler (cars: $19.2 \%$. vans/light trucks: $15 \%$ ). Table 13 shows the selling methods of fleet vehicles used by NAFA's members. Consistent with Runzheimer's survey, a higher percentage of vehicles owned by business fleets was sold to their employees than those owned by government and utility fleets. Also, most government and utility fleet vehicles were sold through wholesale/auction, although the percentage of vehicles sold to employees has increased in the last few years.

The majority of the business fleets have indicated that initial purchase price and job suitability are the most important factors when purchasing or leasing new vehicles [NAFA-NVAS, 1991; Runzheimer, 1991]. California's Vehicle Fleets Survey (VFS-SCAB) indicated that the most important characteristic sought in new vehicles was the reliability. Runzheimer's survey suggested that the leading fleet management problems for business fleets are: (1) Cost of Maintenance and Repair (19\%), (2) Vehicle Disposal (16\%), (3) New Car Price (13\%), and (4) Cost of Gasoline (12\%); while the problems for the government fleets are (1) Cost of Maintenance and Repair (37\%), (2) Cost of Gasoline (28\%), (3) Quality of Car Maintenance and Repair (11\%), and (4) New Car Price (8\%), indicating government fleet managers may be less concerned with the initial purchase price. 


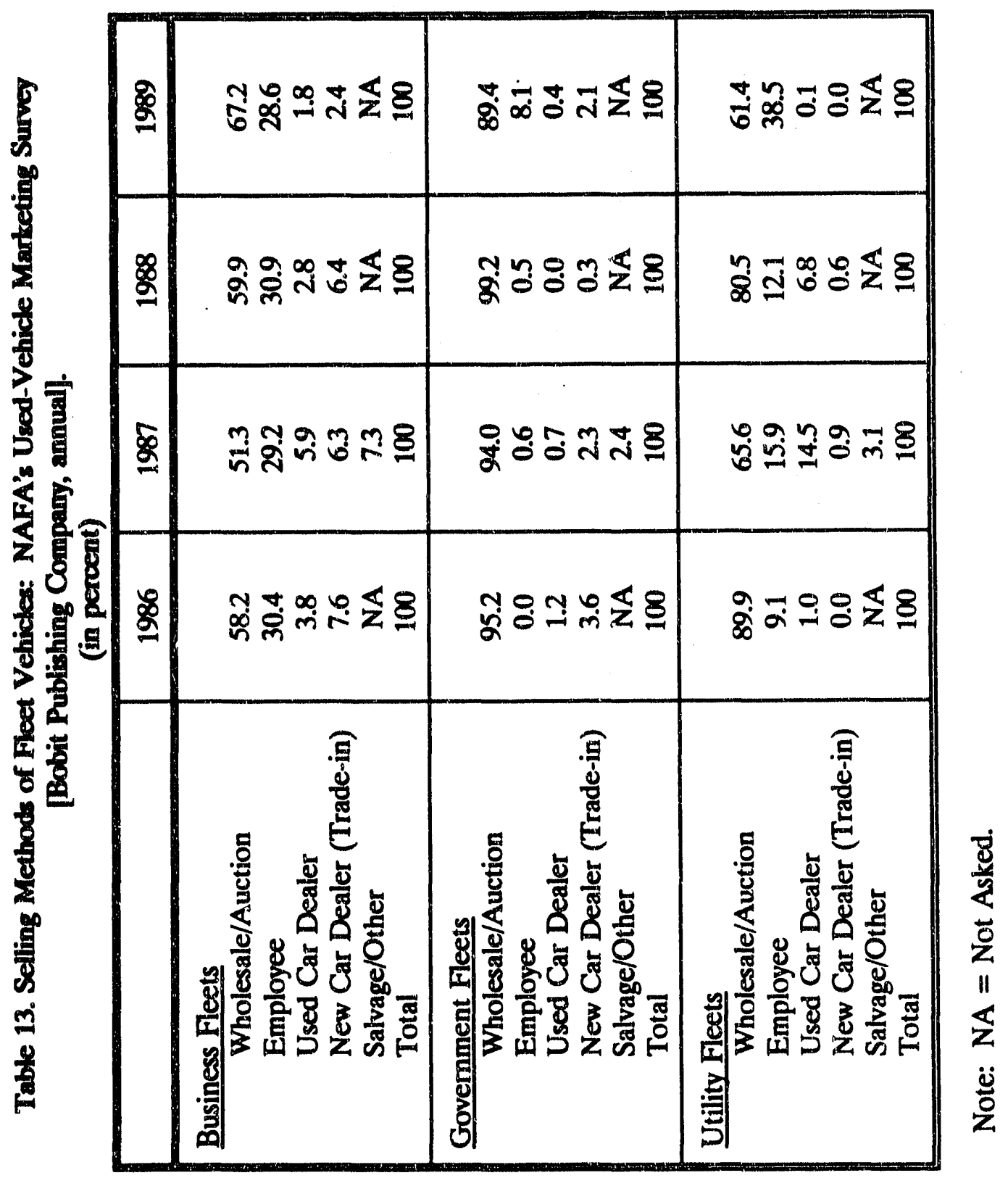




\subsection{FLEET SIZE}

The average fleet sizes for the Nation (as indicated in Runzheimer's survey) are: (1) Business - 231 cars per fleet, (2) Government - 569 cars per fleet, and (3) Utility - 310 cars per fleet. The Oklahoma large fleet survey (OLFS) indicated that the average fleet sizes are: (1) Private Operator 138 vehicles per fleet, (2) Public Operator - 57 vehicles per fleet, (3) Transit - 84 vehicles per fleet, and (4) Oklahoma State Government - 4,127 vehicles. The VFS-SCAB survey in Southern California showed that non-transit fleets had an average fleet size of 198 vehicles. The median fleet size was, however, 33.5 vehicles. The substantial difference between the mean and the median indicates that a relatively small number of very large fleets was included in the sample.

Table 14 shows the estimates of fleet size for five business fleet categories [Easton Consultants, 1991]. The average fleet sizes are 250 vehicles for transit bus fleet, 106 vehicles for school bus fleet, 91 vehicles for taxi/limo fleet, 71 vehicles for service/heavy delivery fleet, and 38 vehicles for repair service fleet.

Most fleet operators do not anticipate any real changes in fleet size in the near future. For example, 57\% of NAFA-NVAS respondents indicated that no changes in their fleet size are planned, $13 \%$ will increase their fleet sizes, and $14 \%$ will reduce their fleet sizes. The VFS-SCAB survey in California showed that most of the new buses will be used to replace the aging ones in the next three years; while $80 \%$ of the new vehicles purchased by the non-transit fleets will replace existing ones in the next 3 years, and only $20 \%$ will be used for fleet expansion. 


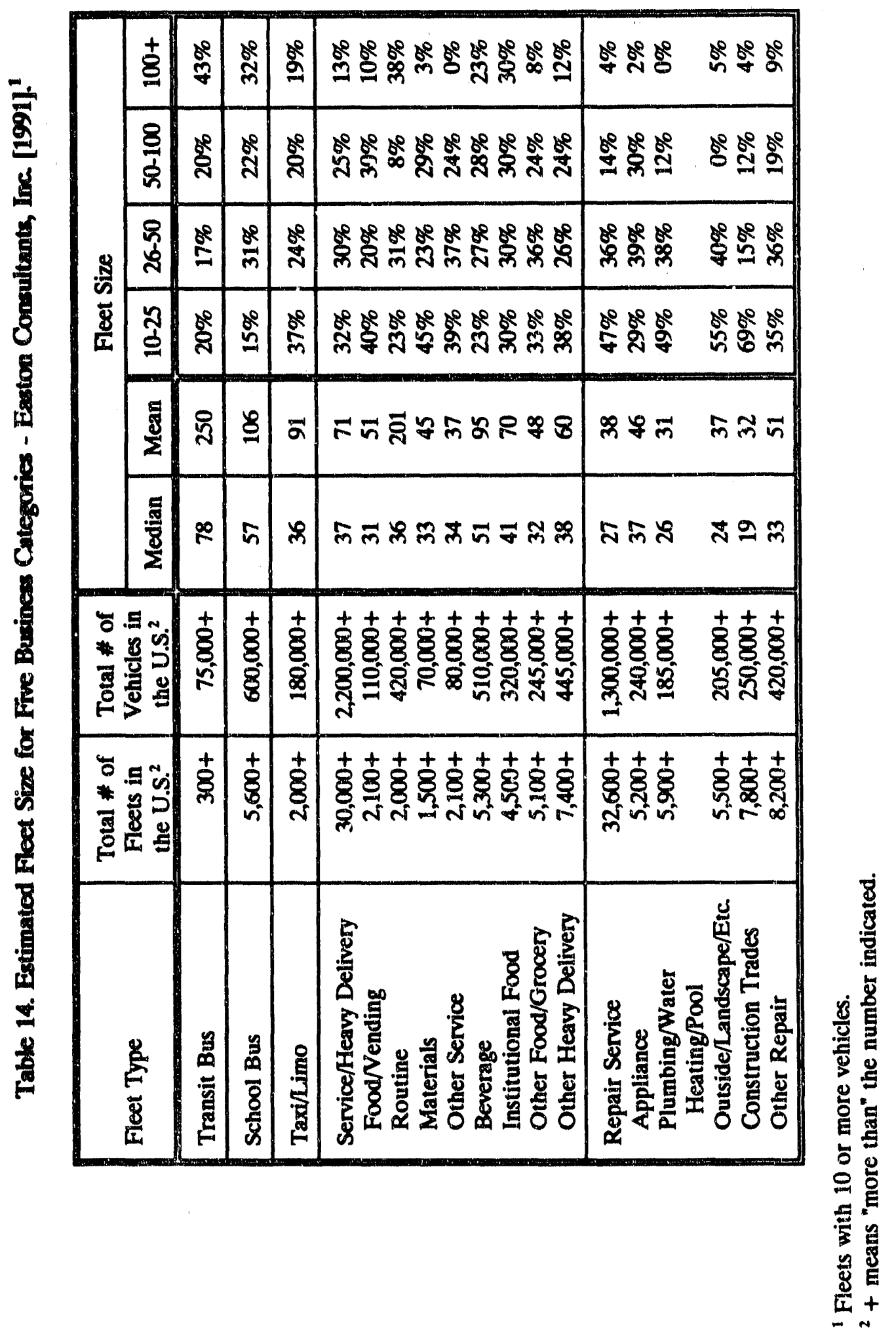




\subsection{ANNUAL VEHICLE MILES AND DALY DRIVING RANGE}

The annual vehicle miles traveled (VMT) by each fleet vehicle and its daily driving range are reported in different studies as follows.

1. Runzheimer (includes all business fleets in the Nation):

Fleet Cars

- $\quad 1987$ - 20,426 miles/year or 81.7 miles/day;

- 1989 - 19,671 miles/year or 78.7 miles/day; and

- $1991-22,121$ miles/year or 88.5 miles/year.

The daily driving range is computed from the annual mileage at 250 operating days per year. The travel includes both business use (about $80 \%$ ) and personal use (about 20\%).

2. OLFS (includes fleet velticies in Oklahoma State only): 10,507 miles/year or 42.0 miles/day (@250 operating days/year). The general vehicle population in Oklahoma operates 12,972 miles per year per vehicle.

3. VFS-SCAB (for Southern California):

- Non-transit fleets: 10,550 miles/year or 42.2 miles/day (@250 operating days/year); and

- Transit fleets (buses): 34,200 miles/year or 136.8 miles/day (@250 operating days/year).

4. IGT (only one fleet operator for each vehicle category was contacted):

- Light-duty trucks/vans: 23,400 miles/year or 75 miles/day;

- Medium trucks - varying from 11,000 to 48,000 miles/year or 35 to 154 miles/day; and

- Transit buses $-34,000$ miles/year or 110 miles/day.

The daily driving ranges were obtained from fleet respondents.

5. GSA (all Federal-civilian-agency in-use domestic vehicles): see Table 11.

6. Based on the data from CFMS, $19.8 \%$ of light-duty commercial fleet vehicles traveled less than 30 miles a day, $26.2 \%$ between 30 and 59 miles a day, $18.6 \%$ between 60 and 89 miles per day, and $35.4 \%$ greater than 90 miles a day. Although $46.0 \%$ of all light-duty vehicles in commercial fleets are typically driven less than 60 miles a day, about 56 to $59 \%$ of these vehicles must occasionally be driven beyond the 60 -mile range. Daily driving range was found to be similar for cars and trucks. However, cars are more likely to take occasional longer trips than trucks. Over $21 \%$ of the establishments responded that it would be easy to assign 
the longer trips to other vehicles, and another $16 \%$ said it would not be difficult to do so. Approximately $21 \%$ of the vehicles surveyed never had to travel over 60 miles a day, and the trip pattern of an additional $9 \%$ could be easily modified to remain within the 60 -mile range. As estimated by this study, over 3.5 million light-duty commercial fleet vehicles typically traveled less than 60 miles a day.

7. AGANGV: Median annual vehicle miles, as well as estimated daily driving range, for five business fleet categories are presented in Table 15 . The daily driving range of a typical business fleet vehicle exceeds 60 miles/day.

8. ORNLDOE study (based on a limited number of fleet operators): annual/daily vehicle miles are computed by business type and vehicle type and are presented in Table 16.

In general, the annual vehicle miles of travel of business fleet vehicles are over 20,000 miles for cars, about 20,000 miles for light trucks/vans, and the mileage for medium and heavy trucks varies from study to study (11,000-65,000 miles). Transit buses were driven over 34,000 miles per year, school buses 15,000 miles/year, and taxi/limo 65,000 miles/year. Vehicles operated by government and utilities tend to be driven less in a year than business fleet vehicles.

The ORNL/DOE study provided some data on the types of areas (urban vs. rural ) where fleet vehicles are typically operated (Table 17). According to the information, most of the travel by fleet cars occurred in urban area (over 38\%) or for interstate travel (over 22\%), rost of the light and medium trucks were engaged in urban travel, and the majority of the travel by heavy trucks in business fleets were interstate travel. 


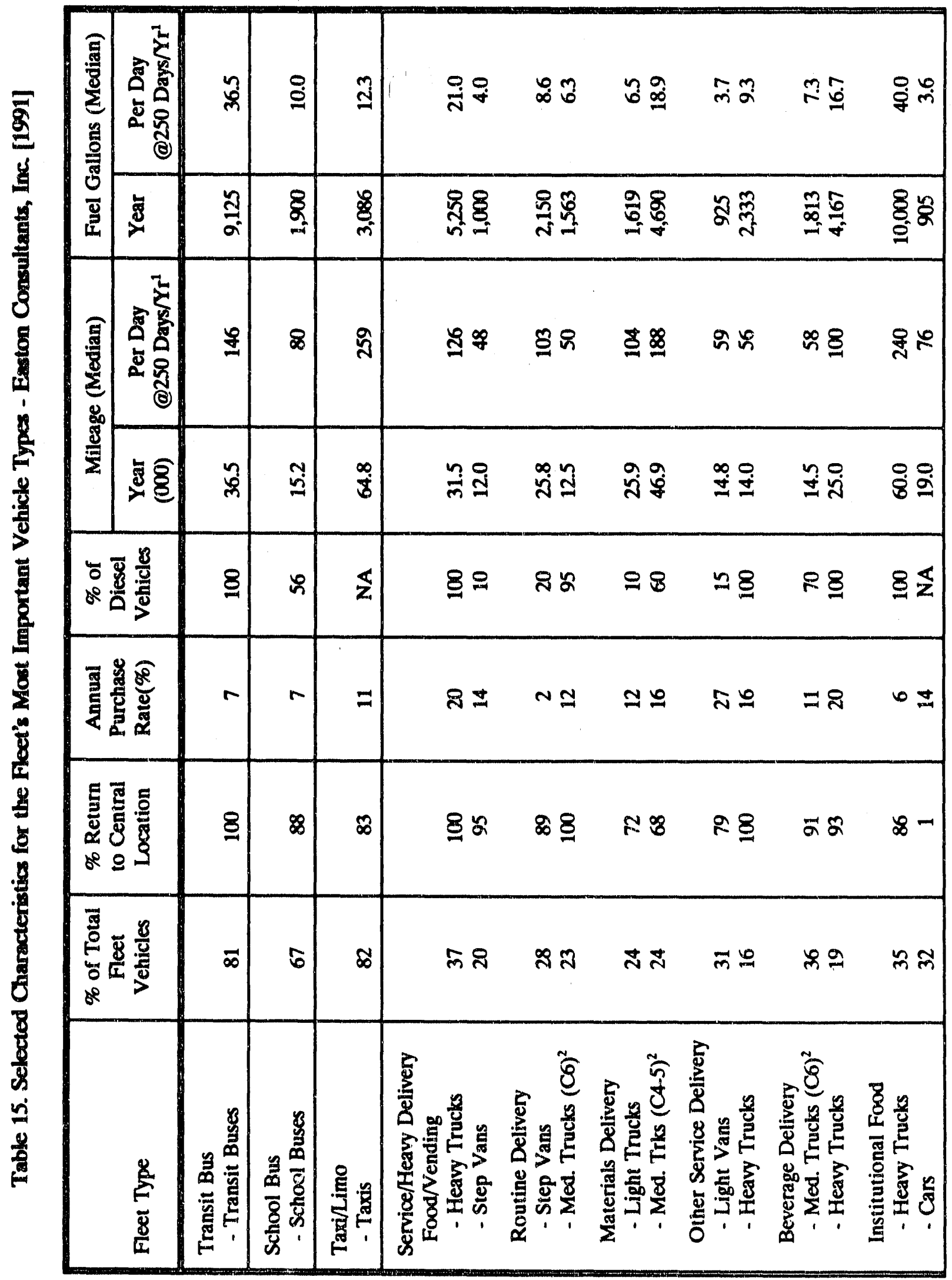


Table 15. (Continued)

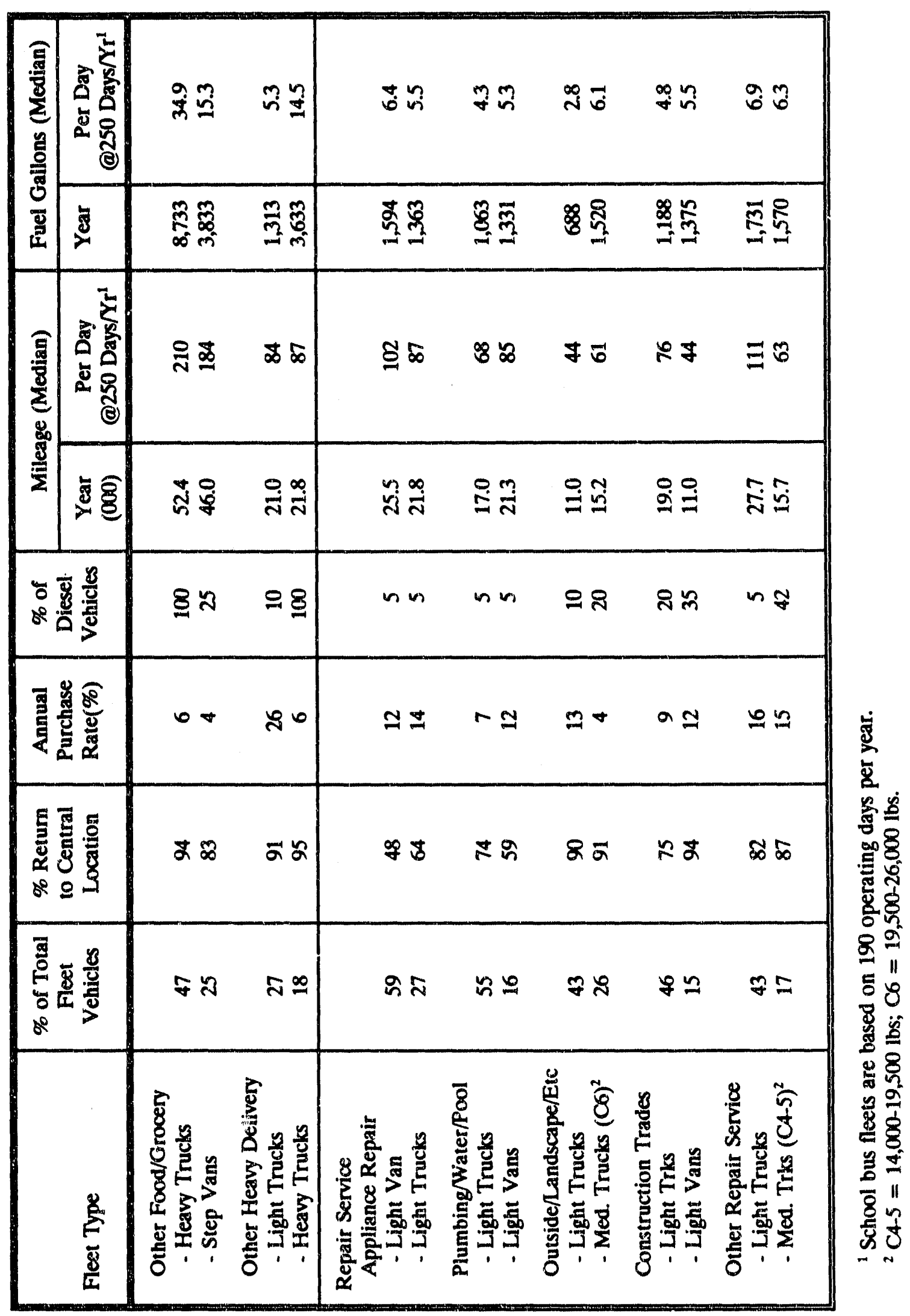




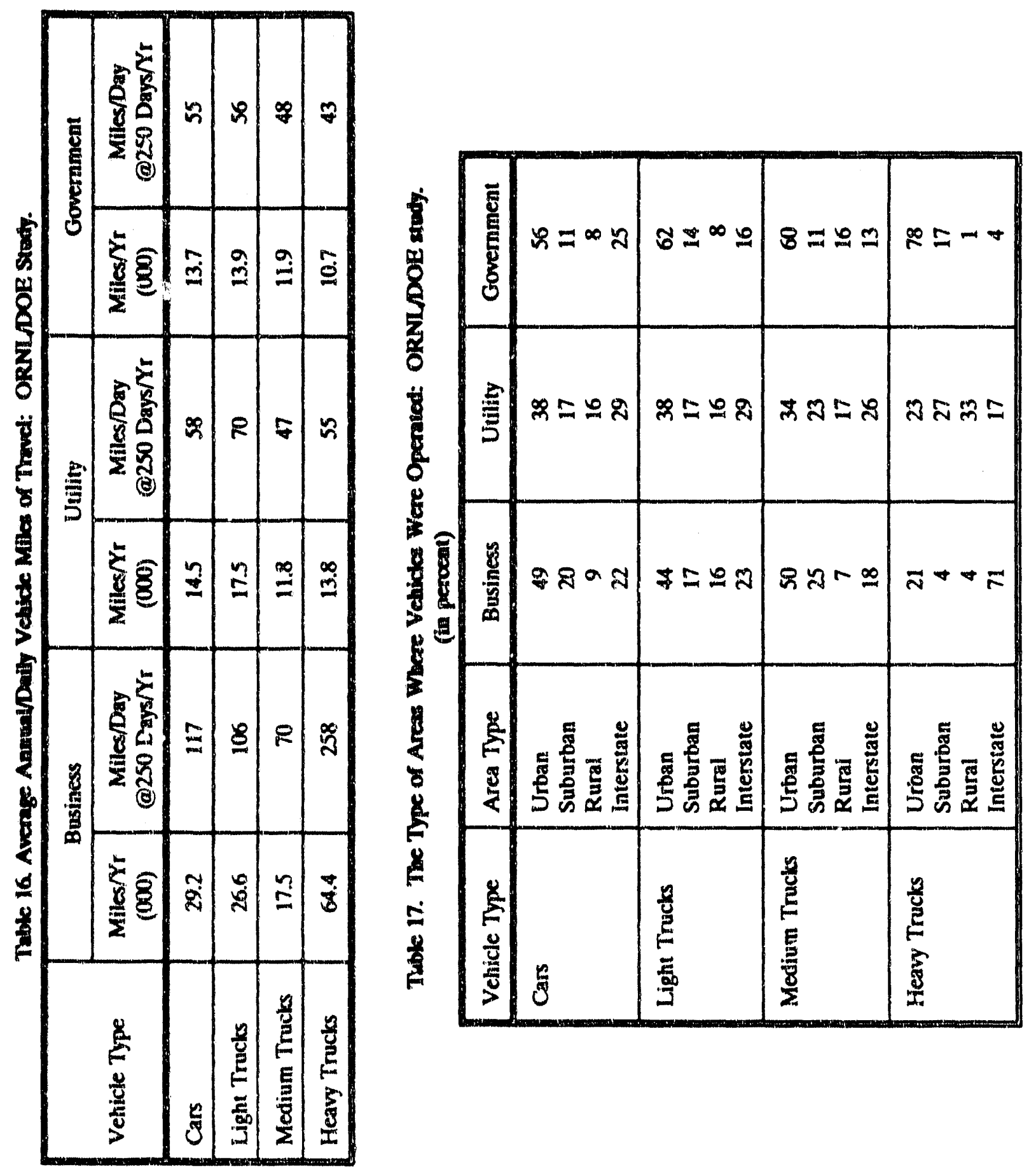




\subsection{NUMBER AND TYPES OF GARAGE LOCATIONS}

For refueling and maintenance purposes, fleets having central garage facilities are more likely to be able to adopt alternative fuel vehicles, such as EVs and CNG-powered vehicles, than fleets that do not have central garage facilities. Vehicles operated by large business fleet operators, as well as utility and government fleet operators (including public transits), are likely to be centrally garaged (see next Chapter).

Very limited statistics are available on this area. AGA/NGV data (Table 15) suggested that the majority of transit bus, school bus, taxi, and those truck/van operated by delivery and repairing services in metropolitan areas do return to a central location. The ORNL/DOE study indicated that the number of vehicles per garage location is about 32 vehicles for large business fleets, 29 vehicles for utility fleets, and 35 vehicles for government fleets. The VFS-SCAB survey suggested that the majority of public and private fleets were based at a single garage. On average, the number of transit buses that are garaged at one location is 139 , while the number for the non-transit vehicles is 75 . Large business fleets investigated in the ORNL/DOE study said that $42 \%$ of their garages are located in central business district/major metro areas (CBDs), $24 \%$ in suburbs, $21 \%$ in rural areas, and $13 \%$ in small cities. The corresponding breakdowns for a limited number of government fleets are $51.2 \%$ in CBDs, $21.8 \%$ in suburbs, $22.8 \%$ in rural areas, and $4.2 \%$ in small cities. 


\subsection{FUELING PRACTICE}

\subsection{FUEL, ECONOMY}

In the Oklahoma study (OLFS), comparisons with the general vehicle population within the State of Oklahoma revealed that fleet vehicles are less fuel efficient than non-fleet vehicles. The reported fuel economy of all vehicles owned by fleet respondents is 11.2 miles per gallon (mpg), of which private operator is $13.4 \mathrm{mpg}$, public operator $7.8 \mathrm{mpg}$, transit operator $10.2 \mathrm{mpg}$, and State government $14.8 \mathrm{mpg}$. (Note that the fuel economy of the entire vehicle population in Oklahoma is $18.3 \mathrm{mpg}$.) The California study (VFS-SCAB) suggested that the fuel economy of transit buses was 3-4.5 mpg, while fuel economy for non-transit fleets, including cars, vans, trucks, buses, was $9.2 \mathrm{mpg}$. Fuel economy was also estimated in the AGANGV study for different business fleets and vehicle types: transit buses $-4 \mathrm{mpg}$, school buses $-8 \mathrm{mpg}$, taxi $-21 \mathrm{mpg}$, light vans/trucks - $16 \mathrm{mpg}$, step vans - $12 \mathrm{mpg}$, medium trucks $-10 \mathrm{mpg}$, and heavy trucks $-6 \mathrm{mpg}$ (see Table 15).

Table 18 presents the VMT-weighted truck mpg by fleet size and area of operation, generated from the 1987 TIUS. The overall truck fuel economy was $8.8 \mathrm{mpg}$. In general, fuel economy decreases as the range of operations increase, indicating that heavier trucks are used more often for long range operations than lighter trucks.

\subsection{CENTRAL FUEIING}

According to the Runzheimer survey, fleets can save on expenses by buying fuel in bulk, and the median cents per gallon saved through bulk purchase in 1991 was 14 cents for business sector, 14.7 cents for utility sector, and 18.5 cents for government sector. The difference in cents per gallon saved between government fleets and business/utility fleets is partly due to the fact that fuel used by government fleets is exempted from fuel taxes. Table 19 shows the percentage of fleets that purchased fuel in bulk. Nearly one-third of the business respondents $(31 \%)$ indicated that the company purchased some types of fuel in bulk. In addition, $30 \%$ of the business respondents said that they purchased gasoline in bulk, $18 \%$ diesel fuel, and less than $0.5 \%$ methanol. As indicated in Runzheimer's report, of those business fleet respondents that operated gasoline storage/supply tanks in their facilities, $71 \%$ of the gasoline consumed was pumped from companies' own fueling facilities. Typically, the types of companies that have fuel tanks in their facilities are those that operated trucks and buses. For example, $90 \%$ of the utility fleets and $50 \%$ of the business fleets with light trucks and vans operate their own fuel tanks. 
Table 18. TIUS 1987 Statistics by Fleet Size and Area of Operation.

\begin{tabular}{|c|c|c|c|c|}
\hline Fleet Size & $\begin{array}{c}\text { Area of } \\
\text { Operation }\end{array}$ & VMT & No. of Vehicles & $\begin{array}{l}\text { VMT-Weighted } \\
\text { MPG }\end{array}$ \\
\hline \multirow[t]{5}{*}{1} & Unknown & $149,801,805$ & 7,742 & 12.9 \\
\hline & Off-road & $2,842,400,156$ & 345,590 & 12.0 \\
\hline & $<50$ miles & $48,665,808,170$ & $4,042,062$ & 12.5 \\
\hline & $50-200$ miles & $20,695,665,496$ & $1,112,417$ & 11.3 \\
\hline & $>200$ miles & $10,164,228,928$ & 241,343 & 6.6 \\
\hline \multirow[t]{5}{*}{$2-5$} & Unknown & 471,837 & 54 & 8.0 \\
\hline & Off-road & $2,395,412,725$ & 342,547 & 10.4 \\
\hline & $<50$ miles & $42,121,570,361$ & $3,847,516$ & 10.9 \\
\hline & $50-200$ miles & $14,559,163,559$ & 734,322 & 9.8 \\
\hline & $>200$ miles & $5,085,254,224$ & 140,512 & 6.3 \\
\hline \multirow[t]{5}{*}{$6-19$} & Unknown & $4,960,036$ & 244 & 5.1 \\
\hline & Off-road & $1,105,603,092$ & 146,813 & 8.8 \\
\hline & $<50$ miles & $22,235,311,188$ & $1,583,323$ & 9.2 \\
\hline & $50-200$ miles & $10,522,588,376$ & 411,949 & 7.6 \\
\hline & $>200$ miles & $5,006,973,648$ & 94,544 & 5.7 \\
\hline \multirow[t]{5}{*}{$>19$} & Unknown & $407,083,195$ & 32,587 & 9.5 \\
\hline & Off-road & $854,632,190$ & 91,689 & 7.5 \\
\hline & $<50$ miles & $19,103,632,346$ & $1,159,614$ & 7.9 \\
\hline & $50 \cdot 200$ miles & $15,736,396,895$ & 443,751 & 6.4 \\
\hline & $>200$ miles & $20,653,817,252$ & 245,264 & 5.5 \\
\hline Total & & $242,310,775,479$ & $15,023,883$ & 8.8 \\
\hline
\end{tabular}

Notes: (1) The fleet size is defined in Chapter 3; (2) VMT = vehicle miles traveled. 


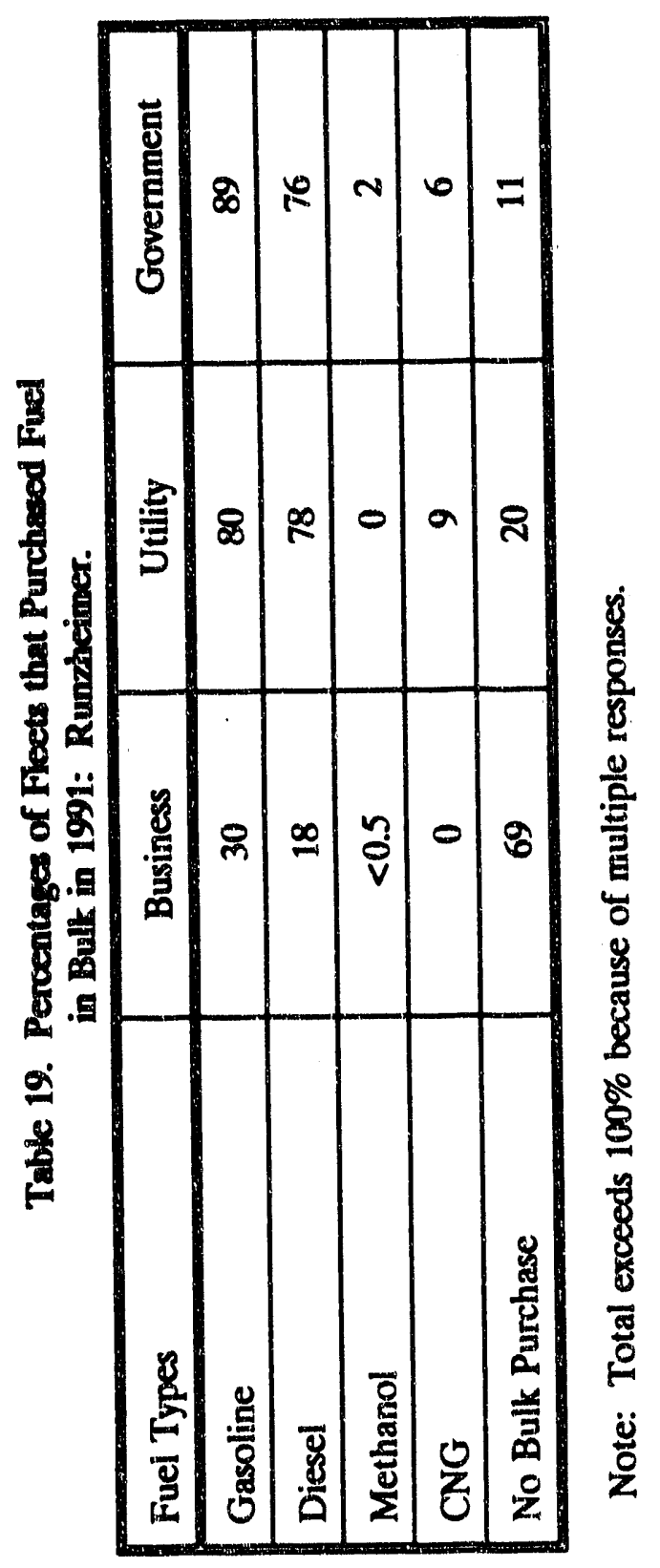


For the five business fleet categories surveyed in the AGANGV study, the percentages of fleets that operate on-site fueling facilities were: transit bus - 97\%; school bus - 93\%; taxi/limo $36 \%$; service/heavy delivery - 65\%; and repair service - $44 \%$ (Table 20). Approximately 74 to $95 \%$ of the fuel consumed by these fleet vehicles was taken from the company's own fueling facilities.

The VFS-SCAB study suggested that large fleets usually use centralized fueling stations, and that public fleets are more likely than private ones to have such facilities. The ORNL/DOE study indicated that most of the small business fleets are not centrally fueled, while over $79 \%$ of the vehicles operated by the three largest business fleets are centrally fueled. The ORNL/DOE study also indicated that over $80 \%$ of the vehicles operated by utility fleets and over $75 \%$ of the vehicles operated by government fleets were centrally fueled.

\subsection{ALTERNATTVE FUEL VEHICLES}

The main alternative fuels, which are considered potential near-term supplements to gasoline, include ethanol, methanol, propane, compressed natural gas (CNG), synthetic fuels, and electricity.

Certain uses of fleets have identifiable characteristics which electric and other alternative vehicle specifications can satisfy. The most promising candidate vehicles for alternative fuels are those that are primarily refueled at a central location, serve a regular route with predictable daily mileage, and have large cargo areas that can accommodate fuel storage tanks or batteries. Some alternative fuels are already in use (Tables 20 and 21). Limited statistics on the performance and operating characteristics of these alternative fuel vehicles are available. The information presented in the following is based mainly on Runzheimer's survey.

Table 21 shows that $24 \%$ of the utility fleet and $13 \%$ of the government fleet respondents are operating some kind of alternative fuel vehicles, while only $2 \%$ of the business fleet respondents indicated so. Of those fleet respondents that have alternative fuel vehicles, the average number of alternative fuel vehicles in the fleet is 51.4 in utility fleets and 33.8 in government fleets, and only 11.5 in business fleets.

Of those fleets with alternative fuel vehicles, the types of vehicles operating on alternative fuels are presented in Table 22. The majority of the alternative fuel vehicles are full-size pickups/vans and passenger cars. Of those fleets with alternative fuel vehicles, the types of alternative fuels used are shown in Table 23. Business fleets comprised mainly propane-powered vehicles, while utility and government fleets comprised both natural gas and propane-powered vehicles. 
Table 20. Fueling Practices of Five Business Fleet Types - Easton Consultants, Inc. [1991]. (in percent)

\begin{tabular}{|c|c|c|c|}
\hline Fleet Type & $\begin{array}{l}\text { Have On- } \\
\text { Site Fueling } \\
\text { Facilities }\end{array}$ & $\begin{array}{c}\% \text { of Fuel Taken } \\
\text { from Company's } \\
\text { Own Facilities }\end{array}$ & $\begin{array}{c}\text { Have } \\
\text { Alternative } \\
\text { Fuel Vehicles } \\
\end{array}$ \\
\hline Transit Bus & 97 & 95 & 18 \\
\hline School Bus & 93 & 93 & 8 \\
\hline Taxi/Limo & 36 & 74 & 6 \\
\hline $\begin{array}{l}\text { Service/Heavy Delivery } \\
\text { Food/Vending } \\
\text { Routine } \\
\text { Materials } \\
\text { Other Service } \\
\text { Beverage } \\
\text { Institutional Food } \\
\text { Other Food/Grocery } \\
\text { Other Heavy Delivery }\end{array}$ & $\begin{array}{l}65 \\
60 \\
69 \\
77 \\
46 \\
68 \\
80 \\
67 \\
72\end{array}$ & $\begin{array}{l}89 \\
92 \\
79 \\
86 \\
78 \\
94 \\
89 \\
89 \\
88\end{array}$ & $\begin{array}{l}18 \\
20 \\
38 \\
11 \\
22 \\
23 \\
10 \\
12 \\
12\end{array}$ \\
\hline $\begin{array}{l}\text { Repair Service } \\
\text { Appliance } \\
\text { Plumbing/Water } \\
\text { Heating/Pool } \\
\text { Outside/Landscape/Etc. } \\
\text { Construction Trades } \\
\text { Other Repair }\end{array}$ & $\begin{array}{l}44 \\
36 \\
41 \\
60 \\
46 \\
51\end{array}$ & $\begin{array}{l}82 \\
75 \\
77 \\
\\
78 \\
86 \\
87\end{array}$ & $\begin{array}{r}9 \\
5 \\
8 \\
10 \\
12 \\
6\end{array}$ \\
\hline
\end{tabular}

${ }^{1}$ Most of the alternative fuel vehicles are powered with propane. 
Table 21. Altemative Fuel Vehicles by Business Type: Runzheimer.

\begin{tabular}{|l|c|c|c|c|}
\hline & & Business & Utility & Government \\
\hline $\begin{array}{l}\text { Percentage of fleets with } \\
\text { alternative fuel vehicles }\end{array}$ & & 2 & 24 & 13 \\
\hline $\begin{array}{l}\text { Number of alternative fuel } \\
\text { vehicles in fleet* }\end{array}$ & Average & 11.5 & 51.4 & 33.8 \\
\cline { 2 - 4 } & Median & 11.5 & 51.5 & 16.0 \\
\hline $\begin{array}{l}\text { Percentage of fleet composed } \\
\text { of alternative fuel vehicles* }\end{array}$ & Average & 18 & 17 & 11 \\
\cline { 2 - 5 } & Median & 18 & 2 & 2 \\
\hline
\end{tabular}

Notes: * Of those fleets that have alternative fuel vehicles.

Table 22. Types of Vehicles Operating on Alternative Fuels by Business Soctor: Runzheimer.

(in percent)

\begin{tabular}{|l|c|c|c|}
\hline Vehicles Types & Business & Utility & Government \\
\hline Passenger Cars & 17 & 15 & 21 \\
\hline Minivans & 17 & 5 & 0 \\
\hline Compact Pickups & 0 & 15 & 21 \\
\hline Full-Size Pickups & 33 & 15 & 26 \\
\hline Full-Size Vans & 16 & 35 & 11 \\
\hline Heavy-Duty Trucks & 0 & 10 & 5 \\
\hline Step Vans & 0 & 0 & 11 \\
\hline Buses & 0 & 0 & 0 \\
\hline Other & 16 & 5 & 5 \\
\hline Total & 100 & 100 & 100 \\
\hline
\end{tabular}


Table 23. Types of Alternative Fuels used by Business Sector

(Data source: personal communication with Runzheimer International.)

(in percent)

\begin{tabular}{|l|c|c|c|}
\hline Fuel Types & Business & Utility & Government \\
\hline Natural Gas & 25 & 60 & 61 \\
\hline Propane & 75 & 30 & 50 \\
\hline Electric & 25 & 20 & 0 \\
\hline Methanol & 0 & 10 & 0 \\
\hline Ethanol & 25 & 0 & 0 \\
\hline Other & 0 & 0 & 0 \\
\hline
\end{tabular}

Note: Totais exceed $100 \%$ because of multiple answers.

As to whether there are plans in the near future to change the number of alternative fuel vehicles operating in fleets, most business fleets are reluctant to increase or to try alternative fuel vehicles (Table 24). However, over $22 \%$ of the utility and government fleet respondents are planning on increasing or trying alternative fuel vehicles.

Table 24. Plan to Change the Number of Alternative Fuel Vehicles, the Types of Alternative Fuel Vehicles in 1992: Runzheimer. (in percent)

\begin{tabular}{|l|c|c|c|}
\hline Plan for 1992 & Business & Utility & Government \\
\hline Fleets With Alternative Fuel Vehicles: & 25 & 24 \\
\hline Increase & 3 & 6 & 2 \\
\hline Decrease & 1 & 69 & 74 \\
\hline Same & 96 & 100 & 100 \\
\hline Total & 100 & & 21 \\
\hline Fleets Without Alternative Fuel Vehicles: & 4 & 24 & 53 \\
\hline Add & 75 & 52 & 26 \\
\hline Won't Add & 21 & 24 & 100 \\
\hline Undecided & 100 & 100 & \\
\hline Total & & & \\
\hline
\end{tabular}




\subsection{FUTURE DATA NEEDS}

No comprehensive nationwide fleet vehicle survey is currently available in the U.S. This report summarizes information on fleet vehicle operating/fueling characteristics using over eleven existing data sources. Whenever possible, these characteristics are presented by business type and vehicle configuration. However, these data sources are incompatible in many cases, and data provided by these data sources are oftentimes sparse. Information summarized in this report focuses on (1) vehicle composition by size, make, business program, and weight, (2) vehicle operating characteristics, such as vehicle replacement cycle, fleet size, annual/daily vehicle miles of travel, the areas (e.g., rural, suburbs, urban) where fleet vehicles are operated, and the number and types of garage locations, (3) fueling practices, including fuel economy, the types of fuel used, and whether the vehicles are centrally fueled.

The areas where data are particularly lacking include vehicle weight (or payload), the areas where fleet vehicles are operated (e.g., rural, suburbs, urban), and the number and types of garage locations. Although average daily driving range can be estimated from annual vehicle miles of travel, the detailed distribution of daily vehicle trips by driving range is not available. To help assess the potential fleet market of alternative fuel vehicles, "trip-based" data are particularly useful since they can address the issues on "where", "how", and "why" the trips are made, and "who" makes them. It is recommended that more "trip-based" data on fleet vehicles be collected in the future. 


\subsection{REFERENCES}

1. Berg, M.R., M.J. Converse, and D.H. Hill, Electric Vehicles in Commercial Sector Applications: A Study of Market Potential and Vehicle Requirements, prepared for The Detroit Edison Company, by the Institute for Social Research at the University of Michigan, Ann Arbor, MI, July 1984.

2. Bevilacqua-Knight, Inc., Potential Market for an Electric-Powered Van in the Extended Detroit Metropolitan Area, report on a survey commissioned for the Detroit Edison Company by the Electric Vehicle Development Corporation, Oakland, CA, November 1987.

3. Biederman, R.T. and C.F. Blazek, Economic Analysis of Low-Pressure Natural Gas Vehicle Storage Technology, report prepared by Institute of Gas Technology for Gas Research Institute, Chicago, IL, April, 1990.

4. Bobit Publishing Company, Automotive Fleet: Fact Book, annual, Redondo Beach, CA.

5. Davis, S.C. and P.S. Hu, Transportation Energy Data Book: Edition 11, ORNL-6649, Oak Ridge National Laboratory, Oak Ridge, TN, January 1991.

6. Easton Consultants, Inc., Natural Gas Vehicle Fleet Market Stuty, Prepared for the American Gas Association and NGV Coalition, December 1991.

7. Federal Highway Administration (FHWA), Highway Statistics, U.S. Department of Transportation, annual.

8. Marshment, R.S., Fuel Consumption and Vehicle Miles of Travel by Large Fleet Operators in the State of Oklahoma, paper presented at the Transportation Research Board 70th Annual Meeting, January 13-17, 1991, Washington DC.

9. Motor Vehicle Manufacturers Association (MVMA), MVMA Motor Vehicle: Facts \& Figures, annual, Detroit, MI.

10. National Association of Fleet Administration, Inc. (NAFA), NAFA Fleet Executive, including NAFA's Used Vehicle Marketing Survey and NAFA's New Vehicle Acquisition Survey, January and February, 1991.

11. Runzheimer International, Survey \& Analysis of Business Car Policies \& Costs; 1991-1992, Northbrook, Illinois, 1991.

12. Shonka, D.B., Characteristics of Automotive Fleets in the United States: 1966-1977, ORNL/TM-6449, Oak Ridge National Laboratory, Oak Ridge, TN, 1978.

13. Shonka, D.B., An Analysis of the NAFA Fleet Data Base: Passenger Cars Only, Brookhaven National Laboratory, Upton, NY, September 1980. 
14. U.S. Department of Commerce, Bureau of the Census, Census of Transportation: Truck Inventory and Use Survey - United States, every 5 years (e.g., 1977, 1982, 1987).

15. U.S. General Services Administration (GSA), Federal Motor Vehicle Fleet Report, for fiscal year 1988, September 1990.

16. Wachs, M. and N. Levine, Vehicle Fleets in the South Coast Air Basin, report prepared by Urban Innovations Group for the South Coast Air Quality Management District, October, 1985.

17. Wagner, J.R., Fleet Operator Data Book (Summer 1977 Data), Volume 1: National Data, BNL-50904, Brookhaven National Laboratory, Upton, NY, September 1979. 


\section{APPENDIX A \\ ORNL/DOE STUDY}

The ORNL/DOE study data were collected via a discussion guide. Both phone and mailout contacts were used. A selected number of fleet operators was contacted during October-December, 1991. The Environmental Protection Agency at Michigan, GE Capital Fleet Services, and PHH Corporation have participated in gathering the information from these fleet operators. The main purpose of this information collection effort was to provide supplementary information on vehicle miles of travel, fleet vehicles' garage locations (central business district, suburban, small city, or rural area), and fueling practices. The data were collected from three major fleet sectors: business, utility, and government, and by four vehicle types. Vehicle types included were: cars, light trucks/vans (GVWR < 8,500 lbs), medium trucks (GVWR = 8,500-26,000 lbs), and heavy trucks (GVWR > $26,000 \mathrm{lbs})$. The focus was on fleets with 10 or more vehicles. A total of 33 fleet operators provided information: 21 business ( 2 overnight delivery service and 19 service/retail) fleets, 5 utility fleets, and 7 government (4 State and 3 municipal) fleets. These fleets operate over 162,213 vehicles: 43,258 cars, 38,972 light trucks (vans), 65,800 medium trucks, and 14,783 heavy trucks. The general profile of these fleet participants are presented in Table A-1. Given the data, which may be incomplete in some cases, the major findings on vehicle composition, operating characteristics, and fueling practices of these fleet participants are presented in this appendix whenever applicable. Since these fleet operators were not selected statistically, the result; from this effort should not be used to make inferences of the entire fleet vehicle population.

\section{A1 VEHCLE COMPOSITION}

\section{Fleet Size}

The average fleet sizes for the three business types are: 6,626 vehicles per business fleet, 1,259 vehicles per utility fleet, and more than 2,395 vehicles per government fleet. These fleet sizes are considerably larger than the national averages reported by Runzheimer (see Section 5.2). Business fleets included in the ORNL/DOE data are dominated by three large fleet operators - 2 overnight delivery service fleets and 1 service/retail fleet. These fleets operate more than 110,000 vehicles, which represent about $80 \%$ of the total business fleet vehicles. 


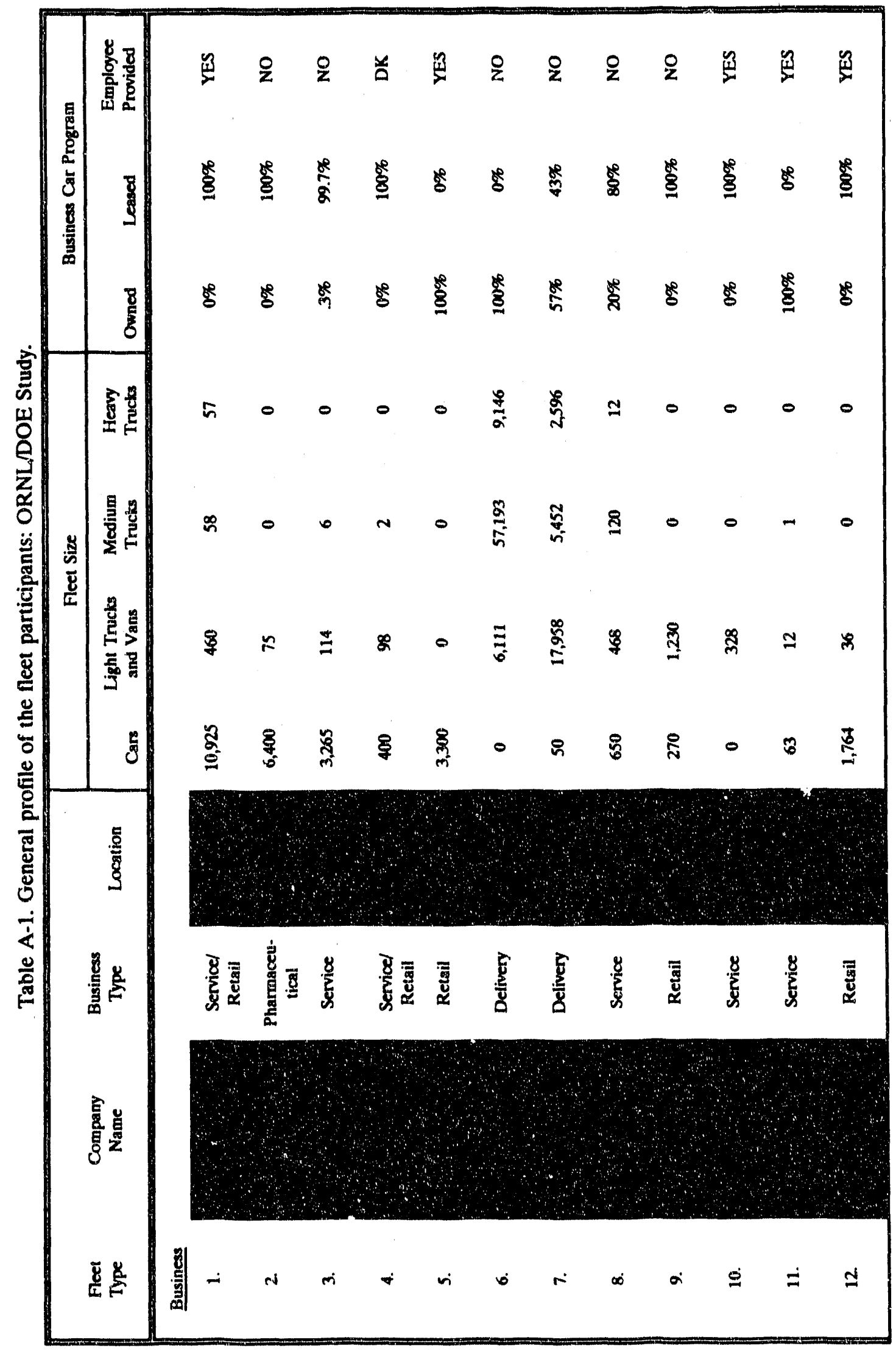


Table A-1. (Continued)

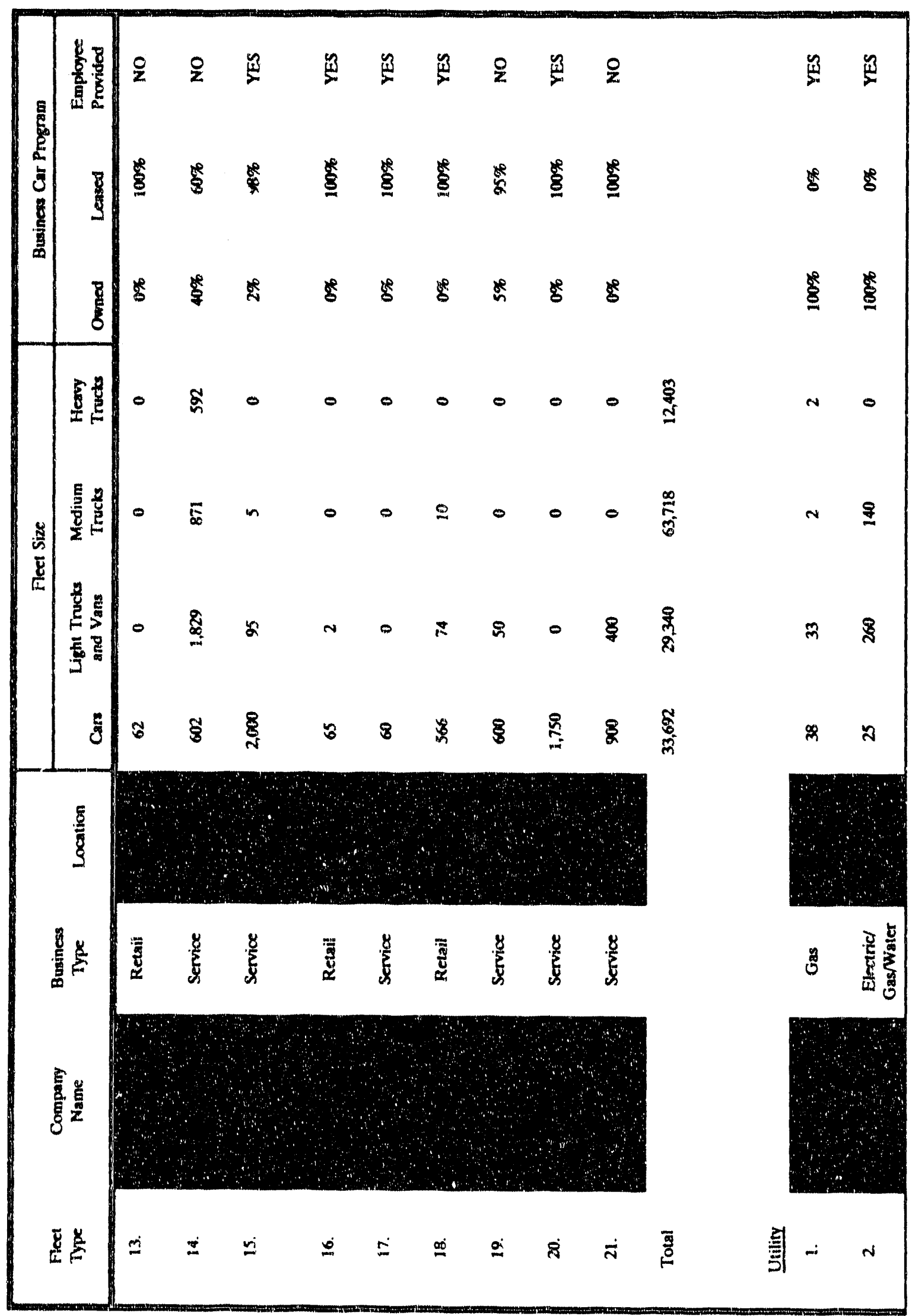


Table A-1. (Contintuxd)

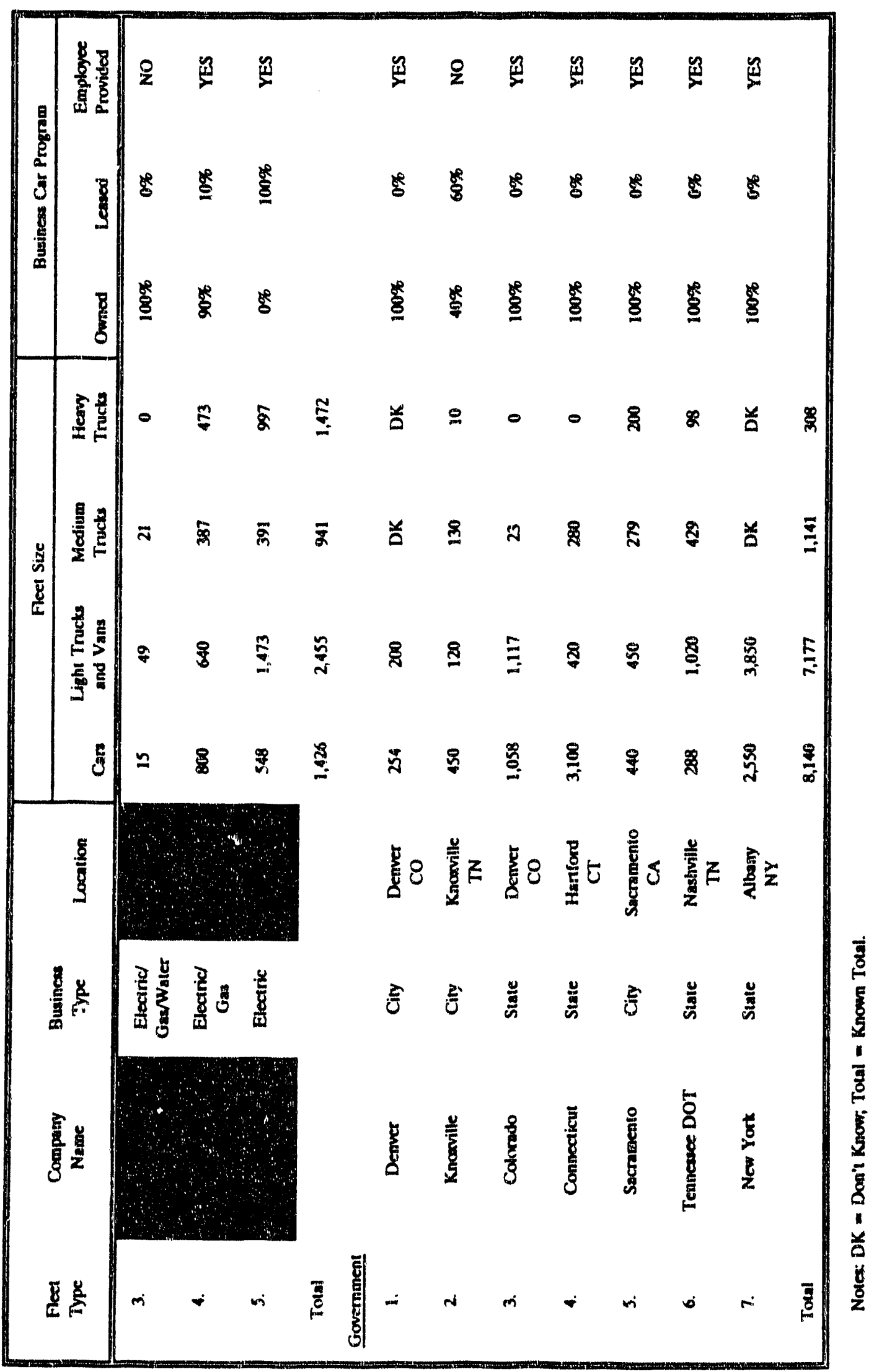


Vehicle Size and Weight

Table A-2 Vehicle Composition by Vehicle Type: ORNL/DOE study.

(in percent)

\begin{tabular}{|l|c|c|c|c|c|}
\hline Fleet Type & Cars & $\begin{array}{c}\text { Light Trucks } \\
\text { \& Vans }\end{array}$ & $\begin{array}{c}\text { Medium } \\
\text { Trucks }\end{array}$ & $\begin{array}{c}\text { Heavy } \\
\text { Trucks }\end{array}$ & Total \\
\hline Business & 24.2 & 21.1 & 45.8 & 8.9 & 100 \\
\hline Utility & 22.6 & 39.0 & 15.0 & 23.4 & 100 \\
\hline Government & 48.5 & 42.8 & 6.8 & 1.8 & 100 \\
\hline
\end{tabular}

\section{Buriness Car Program}

Most of business fleet participants leased vehicles, while government and utility fleets owned most of their vehicles. Twenty percent of business fleets, $78 \%$ of utility fleets, and $91 \%$ of government fleets, owned (as opposed to leased) their vehicles. About $50 \%$ of business fleets, $80 \%$ of utility fleets, and $86 \%$ of government fleets allow operating expenses (including mileage reimbursement) for employees to operate their own vehicles for business purposes. Most fleets indicated, however, that companies have no control over employee-owned vehicles in terms of their fueling practices.

\section{A.2 OPERATING CHARACTERISTICS}

\section{Replacement Plans}

See Table 12 in Chapter 5.

\section{Annual and Daily Driving Range}

See Table 16 in Chapter 5.

Operational Areas (Urban va Rural)

See Table 17 in Chapter 5. 


\section{Number and Types of Garage Locations}

Some fleet operators have difficulties answering these questions, especially those businesses that have branch or division offices across a State or the U.S. For those fleets that centrally garage their vehicles, the ORNL/DOE study indicated that the number of vehicles per garage location is about 32 vehicles for large business fleets, 29 vehicles for utility fleets, and 35 vehicles for government fleets. Large business fleets investigated in the ORNL/DOE study said that $42 \%$ of their garages are located at central business district/major metro areas (CBDs), $24 \%$ at suburbs, $21 \%$ at rural areas, and $13 \%$ at small cities. The corresponding breakdowns for a limited number of government fleets are $51.2 \%$ at C.BDs, $21.8 \%$ at suburbs, $22.8 \%$ at rural areas, and $4.2 \%$ at small cities.

\section{A.3 FUELING PRACTICES}

\section{Truck Fuels}

Table A-3. The Breakouts of Fleet Trucks/Vans by Fuel Type: ORNL/DOE study. (in percent)

\begin{tabular}{|l|c|c|c|}
\hline Fuel Type & Business Fleet & Utility Fleet & Government Fleet \\
\hline Gasoline & 82.4 & 50.6 & 79.4 \\
Diesel & 17.6 & 42.9 & 20.4 \\
CNG/LPG & -0 & 6.5 & 0.2 \\
\hline All Fuels & 100 & 100 & 100 \\
\hline
\end{tabular}

Notes: $C N G=$ Compressed Natural Gas; LPG = Liquified Petroleum Gas.

\section{Central Fueling}

The data indicated that most of the small business fleets are not centrally fueled, while over $79 \%$ of the vehicles operated by the three largest business fleets are centrally fueled. The data also indicated that over $80 \%$ of the vehicles operated by utility fleets and over $75 \%$ of government fleets are centrally fueled.

\section{A.4 LESSONS LEARNED}

Some lessons have been learned from the ORNL/DOE study:

1. There is a need to have a separate vehicie category for vans, station wagons, and jeep-like vehicles when requesting for vehicle information. Without this vehicle category, some fleet operators would include these vehicles in passenger car category, while others would include them in light truck category.

2. When requesting information from government fleet operators, it is essential to be clear on which government agencies within a governmental unit should be included. Some government 
fleet operators report only those vehicles operated by transportation departments; some include those operated by their associated agencies, such as fire department, police department, schools, universities, public utilities (gas/water/electricity), and even National Guard/coast guard, while others do not.

3. There is a need for a clearer definition of "number of garage locations." Some fleet operators had trouble answering how many locations garaged their vehicles over night. Some only reported locations where there were multiple vehicles; while some included locations where one vehicle was at a spot (field offices, private homes, and even motels while on road). In order to get consistent information, perhaps a garage location should be defined as "a central location, which is managed by the company, where 10 or more vehicles are typically parked when these vehicles are not being used." 


\section{INTERNAL DISTRIBUTION}

1. T. J. Blasing

2. F. C. Chen

3. S. C. Davis

4. D. L. Greene

5. E. L. Hillsman

6. P. S. Hu

7. J. Kolb

8. M. A. Kuliasha

9. P. Leiby

10-39. S. P. Miaou
40. D. E. Reichle

41. R. B. Shelton

42. T. J. Wilbanks

43. J. R. Young

44. ORNL Patent Office

45-46. Central Research Library

47. Document Reference Section

48-49. Laboratory Records

50. Laboratory Records--RC

\section{EXTERNAL DISTRIBUTION}

51. B. B. Buchanan, Professor, Computer Science Department, University of Pittsburgh, 206 Mineral Industries Building, Pittsburgh, PA 15260

52. A. Hirsch, Vice President, Environmental Sciences and Director, Washington Operations, Midwest Research Institute, 5109 Leesburg Pike, Suite 414, Falls Church, Virginia 22041

53. H. M. Ingram, Director, Udal Center for Studies in Public Policy, The University of Arizona, 803/811 East First Street, Tucson, Arizona 85719

54. C. D. MacCraken, President, Calmac Manufacturing Corporation, P.O. Box 710, Englewood, New Jersey 07631

55. J. B. Shrago, Director, Office of Technology Transfer, 405 Kirkland Hall, Vanderbilt University, Nashville, Tennessee 37240

56. M. Williams, Professor, Department of Economics, Northern Illinois University, DeKalb, Illinois 60115

57-106. Center for Transportation Analysis, Energy Division

107-116. OSTI, U.S. Department of Energy, P.O. Box 62, Oak Ridge, TN 37831

117. Office of Assistant Manager of Energy Research and Development, DOE/ORO, P.O. Box 2001, Oak Ridge, TN 37831-8600 
,
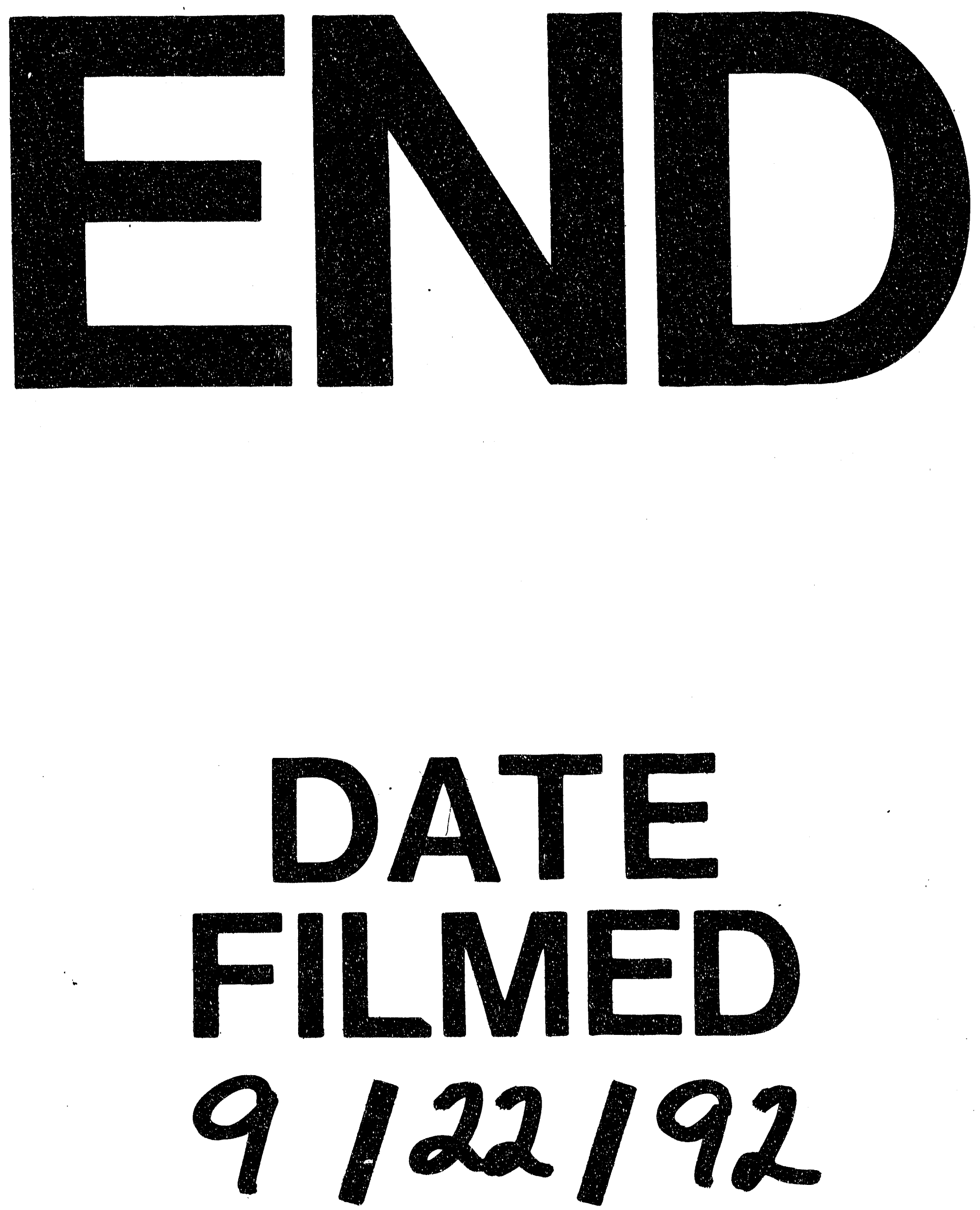

亲 


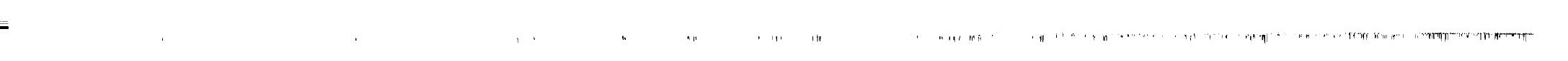

